\title{
Kadınların Namaz Kılma Şekliyle İlgili Rivayetlerin Değerlendirilmesi*
}

\section{Evaluation of the Narrations Related to the Women's Ways of Prayer}

\section{Zeynep Sena Yılmaz}

Doktora Öğrencisi, Necmettin Erbakan Üniversitesi, Sosyal Bilimler Enstitüsü, Hadis Bilim Dalı PhD. Student, Necmettin Erbakan University, Social Sicences Institute, Department of Hadith Konya / Turkey

zeynepsena.yilmaz@ogr.erbakan.edu.tr | https://orcid.org/0000-0003-1388-3618

Article Type / Makale Tipi

Research Article / Araștırma Makalesi

DOI: $10.33420 /$ marife.916619
Article Information / Makale Bilgisi

Received / Gelis Tarihi: 15.04.2021

Accepted / Kabul Tarihi: 18.06.2021

Published / Yayın Tarihi: 30.06.2021

Cite as / Atıf: Yılmaz, Sena Yılmaz. "Kadınların Namaz Kılma Şekliyle İlgili Rivayetlerin Değerlendirilmesi". Marife 21/1 (2021), 541-570. https://doi.org/10.33420/marife.916619

Plagiarism / Intihal: This article has been reviewed by at least two referees and scanned via a plagiarism software. / Bu makale, en az iki hakem tarafından incelendi ve intihal içermediği teyit edildi.

\section{(c) (i) $\odot$}

Copyright / Telif Hakkl: "This article is an open access article distributed under the terms and conditions of the Creative Commons Attribution-NonCommercial-NoDerivatives 4.0 (CC BY-NC-ND 4.0) International License." / "Bu makale Creative Commons Alıntı-GayriTicari-Türetilemez 4.0 (CC BY-NCND 4.0) Uluslararası Lisansı altında lisanslanmıștır."

Ethical Statement / Etik Beyan: * This article is a revised version of the paper presented at the 2nd Hadith Graduate Student Symposium organized by Istanbul University Faculty of Theology, Department of Hadith on 19 November 2020. / Bu makale, 19 Kasım 2020 tarihinde İstanbul Üniversitesi İlahiyat Fakültesi Hadis Anabilim Dalı tarafından düzenlenen 2. Hadis Lisansüstü Öğrenci Sempozyumu'nda sunulan tebliğin gözden geçirilmiş halidir. 


\section{Kadınların Namaz Kılma Şekliyle İlgili Rivayetlerin Değerlendirilmesi}

Özet

İslam dininin önemli şiarlarından biri olan namaz, Kur'an-ı Kerim'de birçok ayette zikredilmiş ancak klyam, kıraat, rükû ve secde rükünlerinin isimleri haricinde namazın nasıl kılınacağı konusunda ayrıntılı bilgi verilmemiştir. Hz. Peygamber ashabına namazın hangi vakitlerde, kaç rekat ve nasıl kılınacağını, namaz içerisinde nelerin, nasıl okunacağını, namazın kabulüne nelerin zarar vereceğini sözlü ve fiili olarak öğretip açıklamıștır. Hz. Peygamber (s.a.s.) kadın erkek ayrımı yapmaksızın bütün müslümanlara "kendisi nasıl kılıyorsa öyle namaz kılmalarını" emretmiştir. ${ }^{1}$ Bununla birlikte onu farklı zamanlarda gören sahabilerden farklı uygulamalar nakledilmiştir. Yani rükünlerin farklı uygulanmasının kaynağı da bizzat Rasulullah'tır.

Kadın olsun erkek olsun gerekli şartları taşıyan ve İslam dinine mensup her fert için namazın hükmü, rükünleri aynıdır. Bununla beraber kadın ve erkeğin namaz kılış şekillerinde bazı farklılıklar mevcuttur. Uygulama açısından herkesin malumu olan bu farklılıklar tekbir getirme, klyamda elleri bağlama, rükû, secde ve teșehhüd rükünlerinde kendini göstermektedir. Temel dini bilgiler için başvuru kaynağı olma özelliğini haiz ilmihaller ve namaz hocası gibi kitaplarda da yaygın olarak kadınların namazı erkeklerden farklı şekilde tarif edilmektedir. Bu tarif kadının, namazın rükünlerini erkeğe göre daha sınırlı șekilde tatbik etmesi șeklinde özetlenebilir. Ancak söz konusu eserler bu farklılıkların kaynağı hakkında detaylı bilgi vermemektedir. Ayrıca günümüzde namazını erkeklerin kıldığı şekilde eda eden hanımların sayısının da bir hayli fazla olduğu görülmektedir. Bireysel boyutunun yanında toplumsal yönü de olan namaz ibadeti mescitlerde eda edildiğinde şahit olunan durumlar bu farklı uygulamaların kaynağını bilmeye duyulan merakı artırmakta, zaman zaman insanların birbirlerine tepki göstermelerine dahi sebep olmaktadır.

Bu çalışmanın amacı, kadınların namaz kılma şekillerindeki farklılı̆̆ın kaynağını tespit edebilmektir. Öncelikle her rükün ile ilgili Hz. Peygamber'in (s.a.s.) uygulamasını haber veren rivayetlerin Kütüb-i Sitte çerçevesinde tespitini, sonrasında ise kadınların namaz kılış şekilleri ile ilgili rivayetlerin tetkikini konu edinen bu araştırma sonucunda kadınların tekbir, secde ve teşehhüdü hususunda rivayetlere ulaşılmış, elleri bağlama ve rükûu ile ilgili merfu ya da mevkuf bir rivayet tespit edilememiştir. Çalışmada mezheplerin konuyla ilgili görüş ve delilleri üzerinde de durulmuştur. Dört mezhepte de rükünleri bakımından namazın eda şekli kadın erkek için aynı olmakla beraber kadınlara mahsus farklı uygulamalardan söz edilmektedir. Mezhepler kadının namazına dair farklı deliller serdetmekle birlikte her biri "kadın avrettir" rivayetini delil olarak almış ve kadının namazı ile ilgili hususlarda görüş belirtirken أستر فَ "(bu) onun için tesettüre daha uygundur" ifadesini zikretmişlerdir. Bu ifadenin yanı sıra mezhepler kadının bazı rükünleri tatbikini erkeğin uygulamasına yakın bir șekilde de tarif etmişlerdir. Ancak Hanefí mezhebinin bu konuda diğer mezheplere göre daha ayrıntılı bir tarife gittiği görülmektedir. Kadın ve erkeğin namazı şekilsel açıdan mukayese edildiğinde en geniş farklılık yine Hanefí kaynaklarda karşımıza çıkmaktadır. Çalışmada Hanefî mezhebinin özellikle kadınların nasıl rükû edeceklerine dair ortaya koyduğu tarifin kaynağı tespit edilmeye çalışılmış ve mezhebin Kur'an'daki rükû emrini anlaması ile kadınların rükûuna dair yaptığı tarifin kendi içerisinde tutarlı olduğu sonucuna varılmıştır.

Anahtar Kelimeler: Hadis, Namaz, Kadınların Namaz Kılışı, Mezhep, İhtilaf.

\section{Evaluation of the Narrations Related to the Women's Ways of Prayer}

\section{Summary}

Prayer, one of the important rules of the religion of Islam, is mentioned in many verses in the Qur'an, but detailed information isn't given on how to perform prayers, except for the names of qiyam, recitation, bowing and prostration. The Prophet has verbally and physically taught and explained to his companions how many rak'ahs there are in different prayers and how the prayer will be performed, what will be read in prayer, what will harm the accuracy of prayer. The Prophet ordered all Muslims to "perform as he is praying" without discriminating between men and women. However,

1 Muhammed b. İsmail el-Buhârî, el-Câmiu's-Sahîh, nşr. M. Züheyr b. Nasr (Beyrut: Daru Tavki'n-Necât, 2001), “Ezân”, 18. 
different applications have been transferred from the companions who saw him at different times. In other words, the source of the different application of the rules of prayer is the Messenger of God himself.

The pillars/rules of the prayer are the same for every individual who has the necessary conditions and is a member of the religion of Islam, be it men or women. However, there are some differences in the way men and women pray. These differences, which are known to everyone in terms of application, are manifested in the opening takbir, tying hands while standing up, bowing, prostration and in the tashahhud pillars. The prayers of women are described differently from men in books such as "prayer teacher" and "catechism" which are reference sources for basic religious information. This description can be summarized as the woman practising the pillars of prayers more limitedly than the man. However, the mentioned works do not give detailed information about the source of these differences. In addition, it is seen that the number of women who perform their prayers as men do today is quite high. When prayer worship, which has a social aspect besides its individual dimension, is performed in mosques. The situations witnessed increase the interest in knowing the source of these different practices, and sometimes even cause people to react to each other.

The aim of this study is to determine the source of the difference in the way women pray. As a result of this research, which firstly deals with the determination of the narrations informing about the application of the Prophet(pnuh) related to each pillar within the framework of Kutub-i Sitte, and then the examination of the narrations about the way women perform prayers, we have found rumors about the takbir, prostration and tasahhud of women. On the other hand, about tying the hands and bowing neither marfu nor mawkuf narrations could not be found. The views and evidences of the sects were also not emphasized in the study. In four sects, although the pillars of prayer is the same for men and women, different practices specific to women are mentioned. Although the sects presented different evidence of the woman's prayer, each took the narration of "woman is awrah" as evidence and while expressing opinions on the issues related to the woman's prayer, they mentioned that the أستركَ "(this) is more suitable for her in the hijab". In addition to this expression, the sects also describe the practice of women in same pillars in a way close to the practice of man. However, it is seen that the Hanafi sect has a more detailed description in this regard than others. When the prayer of men and women is compared physically, the widest difference is again seen in Hanefi sources. In the study, the source of the Hanafi sect's description of how women will bow, especially, was tried to be determined and it has been concluded that the Hanafi sect's understanding of the bowing in the Qur'an is consistent with its definition of the bowing of women.

Keywords: Hadith, Prayer, Women's Prayer, Sect, Disagreement.

\section{Giriş}

Belli rükünlerle Allah’a kulluğun ifadesi olan namaz ibadeti zahiren şekil ve zikirden ibaret olmakla birlikte asıl mahiyeti huşû ile Allah'a yakarmak ve ona yakınlaşmaktır. ${ }^{2}$ Bilindiği üzere şeklî uygulamalar kulluk bilinci, ihlâs ve tâ'zim ile birleşince ibadet niteliği kazanır. Bu sebeple mana boyutunu öne çıkarıp şekli geri planda bırakmak ya da tam tersi bir yaklaşım sergilemek "ibadeti" eksik anlama ve uygulamaya sebep olur. Hz. Peygamber'in ibadetlerin șeklî yönüne gösterdiği hassasiyet ve verdiği önemden hareketle, şekil mananın koruyucusu olarak değerlendirilebilir. Bu bakımdan çalışmada ele alınacak konu namaz ibadetinin şekilsel yönüyle ilgilidir.

Hz. Peygamber (s.a.s.) gerek söz gerek fiille namazın şeklî yönü üzerinde durmuş, yanlıș uygulamaları düzeltmiș, namazın sıhhatini zedeleyici bir durum söz konusu olduğunda namazın iadesini istemiştir. Bu bilgiler namazın şekilsel yönü-

2 M. Kamil Yaşaroğlu, "Namaz", Türkiye Diyanet Vakfi İslam Ansiklopedisi (İstanbul: TDV Yayınları, 2006), 32/356. 
nün titizlikle yerine getirilmesi gerektiğini ortaya koymaktadır. Burada dikkat çeken diğer bir husus da namazın rükünlerini tatbikte farklı uygulamalarla karşılaşılmasıdır. Söz gelimi tekbir alırken eller göğüs, omuz ve kulak hizasına kadar kaldırılabilmektedir. Ekseriyetle mezhepler üzerinden ele alınan bu farklılıklar netice itibariyle Hz. Peygamber'in uygulamalarına dayanmaktadır. Dört mezhep sünnetin tespiti ve hükümlerin açıklanmasında benimsedikleri farklı usullere dayanarak $\mathrm{Hz}$. Peygamber'den gelen uygulamalardan birini esas almaktadır. Söz gelimi Hanefî ve Mâlikî mezhebi amel eksenli bir sünnet anlayıșı benimserken Şâfiî ve Hanbelî mezhebinde bu anlayış rivayet merkezlidir.

Genellikle mezheplerin görüşleri üzerinden ele alınan konulardan biri de kadınların namaz rükünlerini erkeklerden farklı șekilde eda etmesidir. Söz konusu farklılıklar "namazın sünnetleri" içerisinde ele alınmaktadır. Bu makalede pratik boyutta da karşılığı olan kadınların namaz şekillerindeki farklılığın kaynağı tespit edilmeye çalışılacaktır. Öncelikle her rükün ile ilgili Hz. Peygamber'in (s.a.s.) uygulamasını haber veren rivayetler zikredilecektir. Bu rivayetler tek tek incelenmeyecek rivayetin sıhhatine zarar veren bir husus varsa onun açıklanmasıyla yetinilecektir. Kadınların namaz kılma şekline dair tespit edilen rivayetlerin ise tahric ve değerlendirmesi yapılacaktır. Bu hususta konu, mezheplerin görüşleri çerçevesinde değerlendirildiği için âlimlerin meselelere ilişkin tercih ve delillerine ana hatlarıyla temas edilecektir. Ayrıca kadınların namazı ile ilgili farklılıktan söz etmeleri sebebiyle ilmihal kitaplarındaki açıklamalara da yer verilecektir.

\section{Tekbir}

\subsection{Hz. Peygamber'in Tekbir Alması}

Tekbir kelimesi sözlükte "Yüceltmek, büyük olduğunu kabul etmek" anlamlarına gelir. Terim olarak da "Allahu Ekber" cümlesinin söylenmesini ifade eder. Bu cümle "Allah'ın her şeyden üstün, biricik ve tek olduğunu" haber vermektedir. ${ }^{3}$ Namazın ilk rüknü olan tekbire namaza kendisi ile başlanmasından ötürü "iftitah tekbiri" denir. Aynı zamanda bu rükne "tahrîme tekbiri" de denilmektedir. ${ }^{4}$ Bu ifadenin ne anlama geldiği Hz. Peygamber'in (s.a.s.) bir hadisinde şöyle açıklanmıştır: "Namazın anahtarı temizlik (namaz esnasında gerçekleștirilmesi yasak olanları) haram kllan ise tekbirdir. (Onları) helal kılan șey de selam vermektir." 5

Hz. Peygamber'in (s.a.s.) tekbir alırken ellerini kaldırdığı hususunda herhangi bir ihtilaf yokken, ellerini nereye kadar kaldırdığı konusunda farklı uygulamaları bulunmaktadır. Hz. Peygamber'in tekbir alışı ile ilgili başlıca rivayetler iki başlık altında ele alınacaktır.

3 Saffet Köse, “Tekbir", Türkiye Diyanet Vakfi İslam Ansiklopedisi (İstanbul: TDV Yayınları, 2011), $40 / 341$.

${ }^{4}$ Alâeddîn es-Semerkandî, Tuhfetu'l-Fukahâ (Beyrut: Dâru'l-Kütübi'l-İlmiyye, 1994), 1/96.

${ }^{5}$ Muhammed b. Îsâ et-Tirmizî, es-Sünen, thk. A. Muhammed Şakir vd. (Kahire: Matbaatü Mustafa el-Bâbi, 1975), "Tahâret", 3. 


\subsubsection{Ellerini Kulaklarına Kadar Kaldırması}

Bu başlık altında konu ile alakalı Kütüb-i Sitte'deki rivayetlerden seçilen hadisler, bahsi geçen șeklin hangi ifadelerle zikredildiğini derli toplu olarak göstermesi yönüyle önemlidir.

1. Mâlik b. el-Huveyris (r.a.) şöyle demiştir: "Rasulullah (s.a.s.) tekbir aldı-

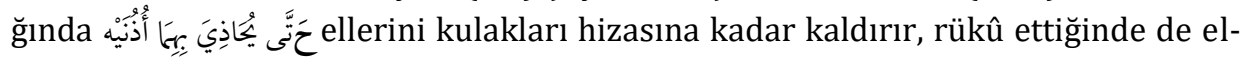
lerini kulakları hizasına kadar kaldırır, bașını rükûdan kaldırdığında "Semi'allâhu limen hamideh" deyip yine bu şekilde yapardı ${ }^{6}$

2. Berâ (b. Âzib) (r.a.) şöyle demiştir: "Allah Rasulü (s.a.s.) namaza başlarken ellerini kulaklarının yakınına kadar kaldırırdı. Sonra (ilk tekbirden başka yerde) bir daha bunu tekrarlamazd.."7

Yukarıdaki rivayetler, Hz. Peygamber'in namaza başlarken ellerini kulaklarına kadar kaldırdığını haber vermektedir. Hanefî mezhebinin görüşü, elleri başparmaklar kulak yumuşağına, diğer parmak uçları da kulak hizasına gelecek şekilde kaldırmaktır. ${ }^{8}$

\subsubsection{Ellerini Omuzlarına Kadar Kaldırması}

1. İbn Ömer (r.a.) şöyle demiştir: "Hz. Peygamber'in (s.a.s.) namaza tekbirle

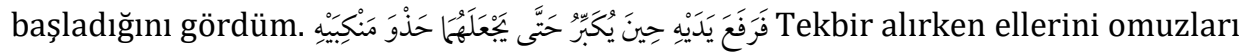
hizasına kadar kaldırdı. Tekbir alıp rükûa giderken de böyle yaptı." Semi'allâhu limen hamideh" derken de böyle yaptı ve "Rabbenâ ve leke'l-hamd" dedi. Ancak secdeye giderken ve secdeden başını kaldırırken bunu yapmadı." ${ }^{9}$

2. Ebû Humeyd (r.a.) şöyle demiştir: "Ben Hz. Peygamber'in (s.a.s.) namazını

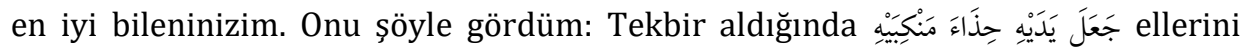

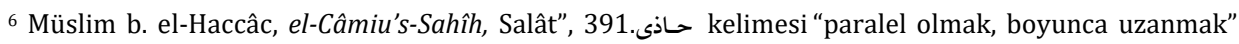
anlamlarına gelir. حَذْوُو وحِذَاء kelimeleri ise “hizasına, karşısına” anlamlarına gelmekte ve muzâf olarak karşımıza çıkmaktadır. bk. Mecdüddîn İbnü’l-Esîr, en-Nihâye, 1/357-358. Hadis aynı sahabiden farklı

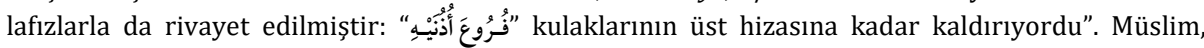
"Salât", 391. Buhârî ö. (256/870) bu hadisi "Kitâbü’l Ezan” ın 8. babında farklı ravilerden tahrîç etmiştir. Onun verdiği metinde "kulakların üst hizasına kadar" ibaresi yer almamaktadır. Hadiste

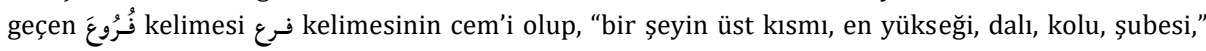
demektir. bk. Cemâlüddîn İbn Manzûr, Lisânü'l-'Arab, 7/246. Aynı sahabiden gelen diğer rivayet: حِيَاَ ellerini kulakları hizasına kadar kaldırırdı”, şeklindedir. Ahmed b. Şuayb b. Ali en-Nesâî, es-Sünen, “İftitâh”, 4. حِيَّ kelimesi “...karşısında” demektir. bk. İbnü’l-Esîr, en-Nihâye, 1/470.

7 Ebû Dâvûd es-Sicistânî, es-Sünen (Beyrut: el-Mektebetü’l-Asriyye, ts.), "Salât", 116. Buhârî bu hadisi zayıf kabul etmiştir. Hadis hafızları "bir daha tekrarlamazdı" cümlesinin Yezid tarafından idrâc edildiği konusunda ittifak etmişlerdir. Ebû Dâvûd, Sünen-i Ebû Dâvûd Terceme ve Şerhi, çev. İ. Lütfi Çakan (İstanbul: Şamil Yayınevi, 1987), 1/150.

${ }^{8}$ Ebû Bekr es-Serahsî, el-Mebsût (Beyrut: Dâru'l-Mârife, 1413), 1/12.

9 Buhârî, "Ezan", 85; Müslim, "Salât", 390; Mâlik b. Enes, el-Muvattâ, thk. B. Avvâd Ma'ruf vd. (Beyrut: Müessesetu'r-Risâle, 1992), "Vukûtü's-Salât”, 204. 
omuz hizasına kaldırırdı..."10

$\mathrm{Bu}$ iki rivayet Hz. Peygamber'in (s.a.s.) ellerini tekbir esnasında omuzlarına kadar kaldırdığını haber vermektedir. Nitekim Mâlik, Şâfiî ve İbn Hanbel de bu görüştedir. Ahmed'den gelen bir diğer görüş ise ellerin kulaklar hizasına kadar kaldırılacağıdır. Yani Hanbelî mezhebinde tekbir alırken ellerin kaldırıldığı yer konusunda muhayyerlik vardır demek mümkündür. ${ }^{11}$

Tekbir alırken elleri gögüs hizasına kadar kaldırmanın "soğuk zamanlara mahsus bir özür hali" olduğunu anlatan rivayet şöyledir:

3. Vâil (r.a.) şöyle demiştir: "Hz. Peygamber'in namaza başlayacağında ellerini kulakları hizasına kadar kaldırdığını gördüm. Sonra yanlarına vardığımda üzerlerinde başlıklı giysiler ve aba varken namaza başlayacaklarında ellerini (ancak) göğüslerine kadar kaldırdıklarını gördüm." 12

Diğer bir rivayette Vâil (r.a.), bu gelişinin kış mevsiminde olduğunu söylemektedir.13 Bu rivayet Hz. Peygamber'in soğuk havalarda tekbir alırken ellerini, kıyafetinin müsaade etmeyişi sebebiyle göğsüne kadar kaldırdığını haber vermektedir. Tekbir alırken elleri gerek kulak hizasına gerekse omuzlara kadar kaldırmak konusunda gelen rivayetler bu hususta bir genişlik olduğunu göstermektedir.

4. Abdülcebbâr b. Vâil'in babasından nakline göre, Vâil Hz. Peygamber'in

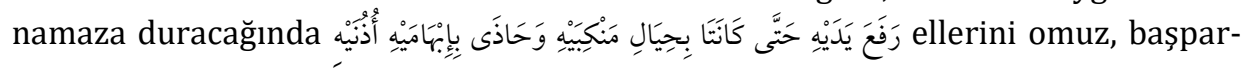
maklarını kulak hizasına kadar kaldırdıktan sonra tekbir aldığını görmüştür. ${ }^{14}$

Nevevî, Şâfîìnin tekbir alırken elleri kaldırma konusunda gelen rivayetleri cem edip rivayetteki tarifi benimsediğini söylemiștir. Ayrıca Şâfiî âlimlerden bir kısmı "omuzlara kadar" ifadesini zahirî olarak anlayıp bu yönde amel etmişlerdir. ${ }^{15}$ Hanefî kaynaklar elleri kulaklara kadar kaldırma hususunda gelen rivayetleri delil almakla birlikte her iki uygulamanın arasını uzlaştırıcı yorumlarda da bulunmuş-

${ }^{10}$ Buhârî, “Ezan”, 145.

${ }^{11}$ Ebû Zekeriyyâ en-Nevevî, el-Minhâc (Beyrut: Dâru İhyai't-Türâsi'l-Arabî, 1972), 6/95; İbn Kudâme, elMuğnî (Kahire: Mektebetü'l-Kâhire, 1968), 1/339.

12 Ebû Dâvud, "Salât", 114. Vâil rivayeti Bedâiu's-Sanâi'de de geçmektedir. Ancak orada "göğüsleri hizasına” yerine "omuzlarına kadar” ifadesi yer almaktadır. Kâsânî, Bedâiu's-Sanâi' (b.y: Dâru'lKütübi'l-İlmiyye, 1986), 1/199. Söz konusu rivayeti temel hadis kaynaklarında Kâsânı̂'nin ö. (587/1191) zikrettiği şekilde tespit edemedik. Hanefî kaynaklar Kâsânî’nin zikrettiği rivayete dayanarak elleri omuzlara kadar kaldırmanın soğuk sebebiyle gerçekleşmesinden dolayı söz konusu fiili özre hamlederler. Serahsî, el-Mebsût, 1/196. Ancak rivayetler incelendiğinde soğuk sebebiyle uygulanmak zorunda kalınan şekil, elleri omuzlara kadar kaldırmak değil gögüs hizasına kadar kaldırmaktır.

13 Ebû Dâvud, "Salât", 115.

14 Ebû Dâvud, "Salât", 114 (Elbânî bu rivayetin zayıf olduğunu söylemiștir. Aslu Sifeti Salâti'n-Nebî 1/203) Her iki uygulamanın arasını cem eder şekilde tarifte bulunan bu rivayet uygulandığında başparmaklar kulak hizasında olursa ellerin omuz hizasının üstünde olacağı görülecektir. Yani rivayetteki tarif uygulanmaya müsait değildir. Râvinin ayrı zamanlarda gördüğü iki fiili birleştirerek zikretmiş olması mümkündür.

15 Nevevî, el-Minhâc, 4/95. 
lardır. ${ }^{16}$

Hz. Peygamber'in (s.a.s.) tekbir alışıyla ilgili farklı tariflerin nakledilmesi sahabenin Allah Rasulü'nü farklı zamanlarda görmelerinden kaynaklanmaktadır. Konuyla ilgili rivayetler tekbir rüknünde ellerin kulaklara, omuzlara ya da gögüslere kadar kaldırıldığı haber vermektedir.

\subsection{Kadınların Tekbir Almasıyla İlgili Rivayetler}

İslam dininin en önemli şiarlarından biri olan namaz, bilindiği gibi kadınerkek her müslümana farzdır. Kadın ve erkeğin namaz kılış şekillerinde bazı küçük farklılıklar mevcuttur. Yukarıda Hz. Peygamber'in (s.a.s.) tekbiri ile ilgili rivayetler ve görüşler üzerinde durulmuştu. Burada hanımların tekbir alması ile ilgili rivayet incelenecektir.

Vâil (r.a.) şöyle demiştir: “... Hz. Peygamber (s.a.s.) bana şöyle dedi: “ يَا وَائلُ بْنْ 'Ey Vâil b. Hucr! Namaza duracağında ellerini kulakların hizasına kadar kaldır. Kadınlar ellerini göğüsleri hizasına kadar kaldırırlar."17 Hadisin senedi şu şekildedir:

Muhammed b. Abdillâh el-Hadramî ö.(297/910)> Meymûne> Ümmü Yahya> Abdülcebbâr b. Vâil> Alkame b. Vâil> Vâil b. Hucr.

Muhammed b. Abdillah el-Hadramî "sika"dır.18 Meymûne ve Ümmü Yahya meçhuldür. Abdülcebbâr b. Vâil'in ö. (112/730) "sika" olmakla birlikte "mürsil" olduğu da söylenmiştir. ${ }^{19}$ Alkame ö. (91-100/710-719?) için "saduk" denmiştir. ${ }^{20}$

Vâil'den oğullarının hadis işitip işitmediği konusunda âlimler farklı görüşler zikretmiştir. ${ }^{21}$ Oğullarının vefat tarihleri net bilinememekle birlikte Alkame'nin yaşının daha büyük olması sebebiyle babasını gördüğü söylenmektedir. Abdülcebbâr'ın mürsil olması ile ilgili olarak, bazı rivayetlerde "Abdülcebbâr'ın aile

${ }^{16}$ Z. Ahmed et-Tehânevî, I'lâü's-Sünen, thk. M.Takî Osmanî (Karaçi: İdarâtu'l-Kurân, 1418/1972), 2/180.

17 Ebü'l-Kâsım et-Taberânî, el-Mu'cemü'l-Kebîr, thk. Hamdi es-Selefî (Mısır: Mektebetü İbn Teymiye, 1994), 22/19. Rivayetin sonunda yer alan "kadınlar ellerini göğüsleri hizasına kadar kaldırırlar" cümlesi, uslüp açısndan birinci cümleye idrac edildiği intibaını uyandırsada bu konuda bir bilgi tespit edilememiștir.

${ }^{18}$ Şemsüddîn ez-Zehebî, es-Siyer, thk. Şuayb Arnavut (Beyrut: Müessesetü'r-Risâle, 1405/1985), 14/42.

19 Ebü'l-Haccâc el-Mizzî, Tehzîbü'l-Kemâl, thk. Beşşâr Avvâd (Beyrut: Müessesetü'r-Risâle, 1980), 16/394; İbn Hacer el-Askalânî, Tehzîbü't-Tehzîb (Hindistan: Matba'atü Dâirati'l-Meârifi'n-Nizâmiyye, 1909), 6/105.

20 Mizzî, Tehzîbüll-Kemâl, 20/312; Zehebî, Târîhu'l-İslâm, thk. Beşşâr Avvâd (Tunus: Dârü'l-Garbi'lİslâmî, 1424/2003), 2/1144; İbn Hacer, Takrîbü't-Tehzîb, thk. Muhammed Avvâme (Suriye: Dârü'rReşîd, 1986), 1/397.

${ }^{21}$ Buhârî, Tirmizî ve İbn Hibbân onun babasının vefatından sonra dünyaya geldiğini söylemișlerdir. Ancak İbn Hacer buna karşı çıkarak şöyle demiștir: "Bu zayıf bir görüştür. Çünkü Abdülcebbâr kendisinin küçük bir çocuk olmasından dolayı babasının namazını tam hatırlayamadığını söyler. Eğer o daha doğmadan babası vefat etmiş olsaydı böyle demezdi." Bezzâr ise bu sözün sahibinin Abdülcebbâr değil Alkame olduğunu söylemektedir. İbn Maîn onun için "sika ve sebt" demiş ve babasına yetişemediğini söylemiştir. İbn Hacer de onun sika ancak mürsil olduğunu haber vermektedir. Mizzî, Tehzîbü'l-Kemâl, 16/394; İbn Hacer, Tehzîbü't-Tehzîb, 6/105. 
fertleri aracılığıyla babası Vâil'den rivayetine göre" ibarelerine rastlanılmaktadır. ${ }^{22}$ Aile fertlerinin kimler olduğu bilinmemekle birlikte Abdülcebbâr'ın ailesi vasıtasıyla babasından öğrendiklerini nakletmesi ihtimal dâhilindedir.

Heysemî ö. (807/1405), Taberânî'nin ö. (360/971) Mu'cem'inde zikrettiği bu rivayet için, Vâil'in yukarıda zikredilen rivayeti ihtivâ eden menkıbesinin Meymûne bint Hucr'dan halası Ümmü Yahya bint Abdilcebbâr vasıtasıyla geldiğini, fakat onu tanımadığını, hadisin diğer ravilerinin ise sika olduğunu söylemektedir. ${ }^{23}$ Tespit edilebildiği kadarıyla bu rivayet zayıftır. Yapılan araştırma neticesinde kadınların nasıl tekbir alacakları ile ilgili Vâil hadisinden başka bir hadise ulaşılamamiştır.

Tâbiînden Hafsa bint Sîrîn ö. (101/719) ve Atâ b. Ebû Rebâh ö. (114/732) kadının tekbir alırken ellerini göğüs hizasına kadar kaldırması gerektiği görüşündedirler. ${ }^{24}$ Ayrıca Ümmü'd-Derdâ el-Vassâbiyye'nin ö. (81/701) tekbir alırken ellerini omuz hizasına kadar kaldırdığı haber verilmektedir. ${ }^{25}$

Mezheplerin konuyla ilgili görüşlerine gelince; Ebû Hanîfe’ye ö. (150/767) göre tekbir alırken elleri kaldırma konusunda kadın erkek gibidir, yani ellerini kulakları hizasına kadar kaldırır. Çünkü eller avret değildir. Ancak Hanefî mezhebinde yaygın olan görüş, kadının tekbir alırken ellerini omuzları hizasına kadar kaldıracağıdır. Bunun açıklaması şu şekildedir: Kadın tekbir alacağında ellerini gögüsleri hizasında, parmak uçları omuzlarına gelecek şekilde kaldırır. ${ }^{26}$ Mâlikî ve Şâfiî mezhebinde kadınlar ellerini omuzlarına kadar kaldırır. Erkekler ve kadınlar arasında bir fark yoktur. Delilleri, daha önce zikredilen İbn Ömer hadisidir. ${ }^{27}$ İbn Hanbel'den kadının ellerini kaldırmasıyla ilgili iki görüş gelmektedir. Birinci görüş kadınların ellerini erkekler gibi kaldıracağını haber verirken, kaldırma miktarının erkeklerden daha az olması gerektiğini söylemektedir. İkinci görüşte ise "kadın tekbir alırken ellerini kaldırmaz" denmektedir. Çünkü kadının kendini sakınması gerekir. $^{28}$

Kadınların tekbir alırken ellerini kaldırmasıyla ilgili bize zayıf da olsa merfu bir rivayetin ulașmış olması, daha sonraki nesillerde de bu uygulamanın devam etmesi bu hadisle amel edildiğini göstermektedir. Bununla birlikte mezheplerden gelen görüşler eller göğüs hizasında parmak uçları omuzlara gelecek şekilde tekbir alma, eller omuz hizasında olacak şekilde tekbir alma ve erkeklerin kaldırdığından daha az kaldırma şeklinde farklılık arz etmektedir.

22 Ebû Dâvud, "Salât", 114, 115.

${ }^{23}$ Heysemî, Mecmau'z-Zevâid, thk. Muhammed Avvâme (Kâhire: Mektebetü'l-Kudsî, 1994), 2/103.

24 İbn Ebî Șeybe, el-Musannef, thk. K. Yusuf el-Hût (Rıyad: Mektebetü'r-Rüşt, 1989), 1/216.

25 İbn Ebî Şeybe, el-Musannef, 1/216; Buhârî, Raf'ul-Yedeyn fi's-Salât, thk. Ahmed eş-Şerîf (Kuveyt: Dâru'l-Erkâm, 1983), 22.

26 Osman b. Ali ez-Zeylâ̂, Tebyînü'l-Hakâyık (Kahire: el-Matbaatü'l-Kübrâ, 1313/1896), 1/109; Zeynüddin İbn Nüceym, el-Bahru'r-Râik (Daru'l-Kütübi'l-İslamî, yy. ts.), 1/322; Ö. Nasuhi Bilmen, Büyük İslam İlmihali (İstanbul: Bilmen Yayınevi, ts.), 120; Lütfi Șentürk-Seyfettin Yazıcl, İslam İlmihali (Ankara: DİB Yayınları, 2009), 132; İlmihal İman ve İbadetler (Ankara: TDV Yayınları, 2016), 252.

27 Muhammed b. İdris eş-Şâfiî, el-Ümm (Beyrut: Dâru'l- Marife, 1990), 1/126; Hasan Çalışkan, Hanımlara İlmihal (Konya: Serhat Kitabevi, 2005), 202.

28 İbn Kudâme, el-Muğnî, 1/340. 


\section{Elleri Bağlama}

\subsection{Hz. Peygamber'in (s.a.s.) Ellerini Bağlaması}

Kıyam, sözlükte "doğrulmak, ayakta durmak, yönelmek" anlamlarına gelir. Kısaca "namazda ayakta durmak" olarak tarif edilen kıyam, iftitâh tekbiri ile her rekâtta kıraat süresini kapsar. ${ }^{29}$

Hz. Peygamber'in (s.a.s.) kıyamda ellerini bağlaması ile ilgili rivayetler să̆ elini sol eli üzerine koyması, sağ eliyle sol elinin bileğini kavraması, sağ elini sol kolunun üzerine koyması, ellerini göğüs, göbek altı ve her ikisi arasına yerleştirmesi şeklinde çeşitlilik arz etmektedir. Bu uygulamaların her biri için başlık oluşturmak konuyu daha da karmaşık hale getireceğinden çalışmanın asıl konusunu göz önünde bulundurarak, belirli bazı bașlıklar olușturma yoluna gidilmiștir. Öncelikle Hz. Peygamber'in kıyamda ellerini bağlamasıyla ilgili rivayetler iki başlık altında ele alınacaktır.

\subsubsection{Sağ Elini Sol Eli Üzere Koymasl}

1. İbn Mes'ûd (r.a.) (bir gün) namaz kllarken sol elini sağ eli üzere koymuş-

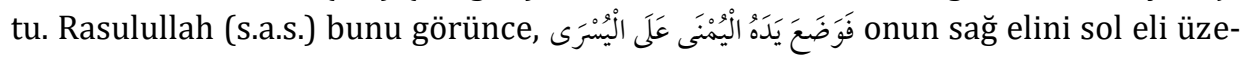
rine koymuştur. ${ }^{30}$

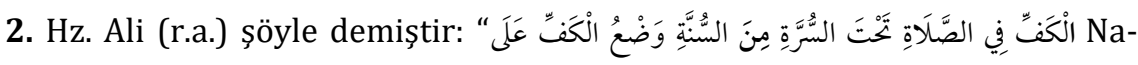
mazda(să̆) eli (sol) el üzere (olacak şekilde) göbeğin altına koymak (namazın) sünnet(in)dendir." 31

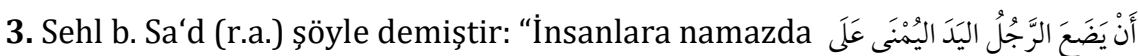

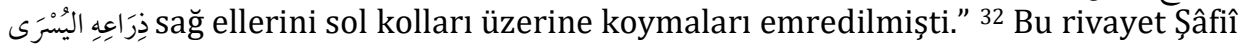
mezhebinin delillerinden olup diğer iki rivayetten farklı olarak sağ elin sol kol üzere konacağını haber vermektedir.

4. Hasen b. Ali, Ebü'l-Velid, Zâide ve İbn Küleyb vasıtasıyla gelen rivayette

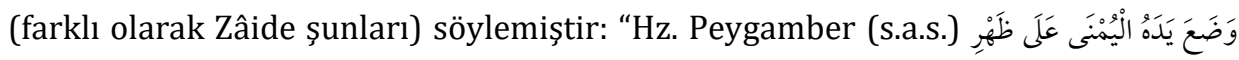
sağ elini sol eli üstüne, kol ve bileğin üzerine yerleștirdi...” ${ }^{33}$

Görüldüğü gibi üçüncü ve dördüncü rivayetlerde ellerin bağlanması konu-

${ }^{29}$ Ebü'l-Kâsım el-Isfahânî, el-Müfredât fi Garîbi'l-Kur'an, thk. S. Adnan Dâvûdî (Dımeşk: Dâru'l-Kalem, 1991), 1/690; Ebubekir Sifil, "Kıyam", Türkiye Diyanet Vakfi İslam Ansiklopedisi (İstanbul: TDV Yayınları, 2002) , 25/514.

${ }^{30}$ Ebû Dâvûd, "Salât",117 (Elbânî hadisin sahih olduğunu söylemiştir. Aslu Sifeti Salâti'n-Nebî, 1/87)

31 Ebû Dâvûd, “Salât”, 117. El kelimesi için “" "كف" kelimeleri kullanılmıştır.

32 Buhârî, "Ezan”, 87. ذراع kolun orta parmak ucundan dirseğe kadar olan kısmı için kullanılır. İbn Manzûr, Lisânü'l-'Arab, 8/93.

${ }^{33}$ Ebû Dâvûd, "Salât", 114. (Elbânî bu hadisin sahih olduğu söylemiştir.) Metinde geçen kolun arasında kalan kısım yani bilek demektir. سـاعد ise bilekten dirseğe kadar olan kısma verilen isimdir. İbn Manzûr, Lisânü'l-'Arab, 8/428, 3/214. 
sunda daha ayrıntılı bilgi verilmektedir. İmam Muhammed'den ö. (181/797) gelen görüş, namaz kılan kimsenin sağ elinin içini sol elinin üzerine koyması gerektiği şeklindedir. ${ }^{34}$ Şâfiî mezhebinde sünnet olan, tekbirden sonra sağ elin sol el üzerine konması, sağ elle sol bileğin bir kısmının ve kolun (bilekle dirsek arası) tutulmasıdır. Sağ el parmaklarını sol bileğe ya da kola yayma konusunda muhayyerlik vardır. Mezhebin bu görüşünün delillerinden biri de yukarıda zikredilen dördüncü hadistir. ${ }^{35}$ Hanbelî mezhebinde müstehap olan sağ elin sol bilek üzerine, kola yakın bir yere konmasıdır. ${ }^{36}$

\subsubsection{Sağ Eliyle Sol Elini Kavraması}

1. Kabîsa b. Hülb babasının şu sözünü nakleder: "Hz. Peygamber (s.a.s.) bize

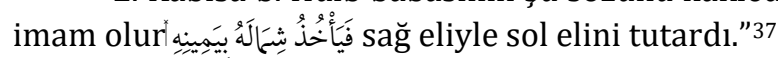

2. Vâil (r.a.) şöyle demiştir: "Hz. Peygamber'in (s.a.s.) namazda kıyamda iken

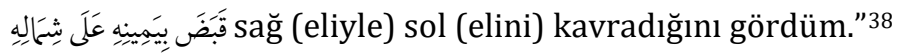

Ebû Yûsuf ö. (182/798) sağ elle sol bileğin tutulması görüşünde iken, daha önce zikredildiği üzere İmam Muhammed sağ eli sol el üzere koyma görüşünü benimsemiştir. Hanefî fakîhlerinden Hinduvânî ö. (362/973) Ebû Yûsuf'un görüşünün ziyade ihtiva etmesi yönüyle daha isabetli olduğunu söylemiştir. Hanefî mezhebinin kâhir ekseriyeti her iki uygulamayı cem etme yoluna gitmiştir. Buna göre kişi kıyamda sağ elin serçe ve başparmağı ile sol bileği halka şeklinde kavrar, böylece (diğer parmaklar da sol kol üzerine yayılmış olur) ${ }^{39}$ Her iki rivayetin farklı zamanlarda uygulandığının söylenmesi de konuyla ilgili hadisleri cem etmenin bir başka yoludur. ${ }^{40}$

Konuyla ilgili yukarıdaki rivayetlerin incelenmesi sonucunda, sağ elin sol el üzerinde olması konusunda bir ihtilaf olmadığı söylenebilir. İhtilaf, bir eli diğerinin üzerine (وضع) koyma ya da biriyle diğerini(قَبَضَ) kavramak üzerine ve bu fiillerin el üzerine mi, bilek üzerine mi yoksa kol üzerine mi olduğu noktasındadır.

Kıyamda ellerin bağlanmasından sonra nereye yerleştirileceği konusunda da farklı rivayetler bulunmaktadır. Bu hususla ilgili rivayetler iki başlık altında ele alınacaktır.

\footnotetext{
${ }^{34}$ Ebû Bekr el-Haddâd, el-Cevheretü'n-Neyyire (b.y: Matbaatü’l-Hayriyye, 1904), 1/51.

35 Nevevî, el-Mecmú' (Beyrut: Dâru'l-Fikr, ts.) 3/310.

36 İbn Kudâme, el-Muğnî, 1/341.

37 Tirmizî," Salât", 73. Kabîsa rivayeti öncekilerden farklı olarak Hz. Peygamber'in kıyamda sağ eli ile sol elini tuttuğunu haber vermektedir. Tirmizî, bu hadisin hasen olduğunu, Hz. Peygamber'in ashabının, tâbiînin ve onlardan sonrakilerin bu hadisle amel ettiğini söylemiştir.

38 Nesâî, "İftitâh", 9 (Bu rivayet için Elbânî sahih demiştir.) Rivayette yer alan قَبَضَ kavrama, tutma anlamlarına gelmektedir. Zıttı yayma, açmadır. İbn Manzur, Lisânü'l-'Arab, 7/213.

${ }^{39}$ Haddâd, el-Cevhere, 1/51; Aynî, el-Binâye (Beyrut: Dâru'l- Kütübi'l-İlmiyye, 2000), 2/181; Zahide Keskin, Uygulama ve Delilleri Açısından Namazda Ellerin Durumu (Rize: Recep Tayyip Erdoğan Üniversitesi, Sosyal Bilimler Enstitüsü, Yüksek Lisans Tezi, 2016), 46.

${ }^{40}$ M. Emin İbn Âbidin, Reddü'l-Muhtar (Beyrut: Dâru'l-Fikr, 1992), 1/487.
} 


\subsubsection{Ellerini Göbek Altında Bağlaması}

1. Hz. Ali (r.a.) şöyle buyurmuştur: "Namaz kılarken (sağ) eli (sol) el üzere göbeğin altında koymak (namazın) sünnet(in)dendir." 41

Bu rivayet sağ eli sol el üzerine koymanın gerekliliği ile ilgili deliller arasında da zikredilmişti. Hz. Ali'nin (r.a.) bu rivayetinin yanı sıra İbn Cerîr'in Hz. Ali'nin namazını haber verdiği şu rivayeti de burada zikretmek uygun olacaktır:

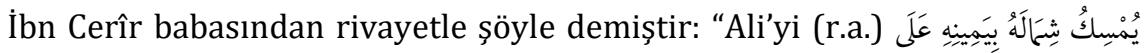
göbeği üzerinde sağ eliyle sol bileğini tutmuş gördüm." 42

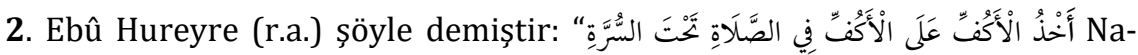
mazda eli el üstüne koymanın yeri göbek altıdır." ${ }^{43}$

Zikredilen bu iki rivayet mevkuf olsa da hükmen merfudur. Zira ibadetin şekli hakkında bilgi vermektedir ve bu bilginin kaynağı da Hz. Peygamber'dir.

Hanefî mezhebinin bu konudaki görüşü elleri göbek altında bağlamaktır. Delilleri Hz. Ali rivayetidir. Söz konusu rivayette geçen "السنة" lafzının mutlak olarak geldiğini, bunun Hz. Peygamber'in sünnetine hamledileceğini söylemektedirler. ${ }^{44}$

\subsubsection{Ellerini Gögüs Üstünde Bağlaması}

1. Vâil (r.a.): "Rasulullah (s.a.s.) ile namaz kıldım. ووضع يَدَهُ الْْيْمَى عَلى يَدِهِ الْيُشْرَى عَلَى صدرِ Sağ elini sol eli üzere gelecek şekilde göğsü üzerine koydu" demiştir. ${ }^{45}$

${ }^{41}$ Ebû Dâvûd, "Salât", 117. Hz. Ali'den gelen bu rivayet müsned merfu kabul edilmiştir. O, bu ifade ile

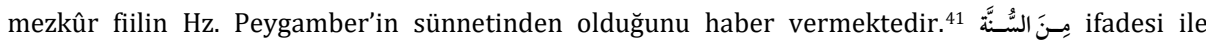
nakledilen rivayetlerin hem merfu hem de mevkuf olmasından söz edilmekle birlikte, muhaddislerin çoğu bu ifadenin geçtiği rivayetlerin merfu olduğu görüşündedir. Muhammed Yllmaz, "Mevkuf Hadisler ve Hükmen Merfu Kavramı", Çukurova Üniversitesi İlahiyat Fakültesi Dergisi 1/1, (2001), 173-174.

42 Ebû Dâvûd, "Salât", 117. Rivayetteki "göbeği üzerine" sözü sağlam bir senetle tespit edilememiștir. Ebû Dâvûd, Sünen-i Ebû Dâvûd Terceme ve Şerhi, çev. İ. Lütfi Çakan, 1/158. Rivayetin ravilerinden Ebû Bedr "göbeği üzerinde" ziyadesini Ebû Talût'tan nakletmede tek kalmıştır. Ebû Bedr için Ebû Hâtim ö. (277/890) "leyyinül hadis" demiș ve rivayetlerinin delil olarak alınamayacağını söylemiștir. Halîl b. Ahmed es-Sehârenpûrî, Bezlü'l-Mechûd, thk. M. İdris Kandehlevî (Beyrut: Dâru'l- Beşâiru'l-İ́slamiyye, 2006), 4/105; Zehebî, es-Siyer, 9/354. Buhârînnin, "namaz içinde amel" bâbında ta'likan zikrettiği bu rivayette "göbeğin üzerinde" ifadesi yer almamaktadır. Buhârî, "el-Amelü fi's-Salât", 1.

${ }^{43}$ Ebû Dâvûd, "Salât", 117.

${ }^{44}$ Serahsî, el-Mebsût, 1/24.

45 Muhammed b.Huzeyme, es-Sahîh, thk. M. Mustafa el-A'zamî (Beyrut: Mektebet'ül-İ́slâmî, 1992), 1/243. Bu rivayetin diğer tarikleri de incelendiğinde Müemmil b. İsmail haricinde metinde "göğsü üzerine" ziyadesini yapan ravi yoktur. Bu da onun rivayetinde tek kaldığını gösterir. Müemmil için Ebû Hâtim: "sünnet konusunda saduktur ancak çok hata ederdi," demiştir. Buhârî onun için "münkeru'l hadis" demektedir. (Buhârî bu cerh ifadesini kendisinden hadis rivayet etmenin helal olmadığı raviler için kullanmaktadır. Abdullah Aydınlı, Hadis Istılahları Sözlüğü (İstanbul: Timaş Yayınları, 1987), 112.) Kitaplarını gömüp ezberinden rivayet etmesi sebebiyle hatasının çok olduğu söylenmiștir. Yani Müemmil'in ziyadesi kabul edilemez. İbn Hacer, Tehzîbü't-Tehzîb, 10/380-381; Tehânevî, İlâü's-Sünen, 2/195; 
2. Tâvûs: "Rasulullah (s.a.s.) namazda sağ elini sol eli üzere koyar sonra da onları göğsü üzerinde bağlardı" demiştir. ${ }^{46}$

$\mathrm{Bu}$ rivayetin mürsel olması dışında bir kusuru yoktur. Ravilerinin durumu Vâil hadisinden daha iyidir. Mürsel hadisin delil olması konusunda farklı görüşler bulunmakla birlikte zayıf kabul edilir. ${ }^{47}$ Burada mürsel rivayetin ve Vâil hadisinin mana yönüyle birbirini desteklediğini söylemek mümkündür. ${ }^{48}$

Şâfiî mezhebinin bu konudaki delili Vâil hadisi olsa da uygulama, elleri göğsün altında göbeğin üstünde bağlama şeklindedir. ${ }^{49}$ Şâfiî mezhebinin bu konudaki bir diğer delili de Kevser sûresi ikinci ayette geçen “وانحر” emridir.50 Mâlikî mezhe-

binde kıyamda eller iki yana salınır. Ellerin bağlanması farz namazlarda mekruh iken nafile namazlarda caizdir. Ancak ellerin salındığı durumlarda namaz uzun sürerse sağ el sol el üzere konabilir. İmam Mâlik'ten gelen diğer görüș de ellerin göğüs altında bağlanacağı şeklindedir. ${ }^{51}$ İbn Hanbel'den bu konuda üç görüş gelmiştir. 0 , ellerin göbeğin altında bağlanabileceğini söylediği gibi göbeğin üzerinde bağlanacağını da söylemiștir. Üçüncü görüşü ise kişilerin bu ikisinden dilediklerini yapma konusunda muhayyer olduklarıdır. ${ }^{52}$

\subsection{Kadınların Ellerini Bağlaması}

Tespit edilebildiği kadarıyla bu konuda günümüze ulaşan kaynaklar içerisinde kadınlara özel bir emir yer almamaktadır. Burada kadının kıyamına dair ulaşılabilen en eski görüş Atâ b. Ebî Rebâh'tan ö. (114/732) gelmektedir.

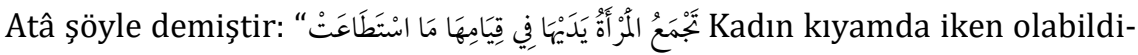
ğince ellerini birbirine yaklaştırır." 53

Hanefî mezhebine göre kadın sağ elinin içini sol elinin sırtına kavramaksızın yerleştirir ve göğsü üzerine koyar. ${ }^{54}$ Şâfiî mezhebinin konuyla ilgili delili Vâil (r.a.) hadisi olmakla birlikte, uygulamada farklılıklar olduğundan daha önce bahsedil-

${ }^{46}$ Ebû Dâvûd, "Salât", 118.

47 Muhaddisler, Şâfiîlerin çoğunluğu, bazı Mâlikîler ve birçok Fıkıh Usulü âlimi mürsel hadisi zayıf kabul ederek delil saymazlar. Ebu Hanîfe, Mâlik b. Enes, Mâlikî ve Hanefî fukahanın ekseriyeti mürsel hadisi mutlak olarak delil sayarlar. Ayrıntılı bilgi için bk. Selahattin Polat, Mürsel Hadisler ve Delil Olma Yönünden Değeri (Ankara: TDV Yayınları, 2010), 117 ve 130.

48 Tehanevî, I'lâü's-Sünen, 2/197.

${ }^{49}$ Nevevî, el-Mecmû, 3/313.

50 "Venhar" sözünden maksadın sağ eli sol elin üzerine koyarak boğazın altına (göğsün üst kısmına) bağlamak olduğu ile ilgili rivayetler gelmiștir. Ahmed b. el-Hüseyin b. Ali Beyhakî, es-Sünenü'l-Kübrâ, thk. Abdülkâdir Atâ (Beyrut: Dâru'l- Kütübi'l-İlmiyye, 2003), 2/46, 47. Ancak rivayetlerin durumu ihticâca el verișli değildir. Zehebî, Mîzânü'l-I'tidâl, thk. A. Muhammed el-Bicâvî, (Beyrut: Dâru'lMârife, 1963), 2/61. Bununla birlikte bu rivayetler Şâfî̂ mezhebinin elleri bağlama konusunda dayandıkları tek delil değildir. Hanefî mezhebi ise "venhar" emri ile bayram namazından sonra kurban kesmenin kastedildiğini söylemektedir. Serahsî, el-Mebsût, 1/24. Ayrıca bk. Fahruddîn erRâzî, Mefâtîhu'l-Gayb (Beyrut: Dâru İhyâi't-Türâsi'l-Arabî, 1420/1999), 32/317-318.

51 Ebubekir Sifil, "Kıyam", 25/514-515; Nevevî, el-Minhâc, 4/114.

52 İbn Kudâme, el-Muğnî, 1/341; Nevevî, el-Mecmû, 3/313.

${ }^{53}$ Abdürrezzak es-San'ânî, el-Musannef (Beyrut: el-Mektebü'l-İslâmî, 1403/1983) 3/137.

54 Mehmed b. Ferâmurz Molla Hüsrev, Dürerü'l-Hükkâm (Beyrut: Dâru İhyai't-Türâsi'l-Arabî, ts.), 1/67; Bilmen, B. İslam İlmihali, 122; A. Fikri Yavuz, İslam İlmihali (İstanbul: Çile Yayınları, ts.), 116. 
miști. Şâfiî kaynaklarda ellerin bağlanması hakkında kadın ve erkek arasında bir farktan söz edilmemiş, sadece kadınların uzuvlarını birbirine yakın tutmaları gerektiğine vurgu yapılmıştır. Kadınların pratikte Vâil hadisiyle (göğüs üzerine koyma) amel etiklerini söylemek yanlış olmayacaktır. Ayrıca sağ elle sol kolun bir kısmının tutulmasının sünnet olduğu görüșü, farklı bir uygulamadan söz edilmediğinden kadınlar için de geçerlidir. 55

Mezheplerin konuyla ilgili görüșlerine bakıldığında kadın ve erkeğin namaz kılma şekilleri arasındaki en geniş farklılığın Hanefî mezhebinde olduğu görülmektedir. Bunun sebebi mezheplerin dayandıkları delillerin farklılık arz etmesindendir. Söz gelimi Hanefî mezhebinde erkekler tekbir alırken ellerini kulaklarına, kadınlar ise göğüs hizasına kadar kaldırmaktadır. Şâfiî mezhebinde tekbir alırken kadın-erkek ellerini omuzları hizasına kadar kaldırır. Bu örnek bize kadının ve erkeğin namaz kılma şekilleri arasındaki farklılığın en çok Hanefî mezhebinde bulunduğunu açıç̧a göstermektedir. Hanefî âlimler namazın kılınışına dair delilleri zikrederken, kadınlara mahsus bir farklılık mevcutsa onun da delilini zikretmişlerdir. Ancak kadının elleri bağlamasıyla ilgili görüşlerini aktarırlarken tespit edilebildiği kadarıyla doğrudan konuya dair bir delil getirmemişlerdir. Onlar daha çok “ 56 hadisini delil göstererek kadının namazda derli-toplu olmasına işaret etmektedirler.

"Kadın avrettir" hadisinin tam hali şöyledir: "Kadın avrettir (mahremdir), dlşarı çıktı̆̆ı zaman şeytan bakışlarını ona doğru çevirir." Bu hadis için Tirmizî ö. (279/892) "hasen sahih garib" demiștir. Bu rivayet şu şekilde de mevcuttur: “...Onun Allah'a en yakın olduğu an evinde olduğu andır." 57 Bezzâr ö. (292/905) bu rivayeti zikrettikten sonra "kadın avrettir" cümlesini Katâde'den sadece Hemmâm'ın naklettiğini söylemiştir. Bu rivayet ile kastedilenin kadının evde oturması olduğu yorumlarının yanında "avret" meselesi, hür kadın için namazını kılarken nasıl örtünmesi gerektiği yani setr-i avret özelinde de değerlendirilmiștir. Bu bağlamda Evzâî ö. (157/774) ve Şâfiî "kadın namaz kılarken eli ve yüzü dışında bütün bedenini örter" demiştir. İbn Abbas'tan (r.a.) geldiği rivayet edilen (روي)

"Kadın tırnağına kadar avrettir" sözü üzerine Ahmed b. Hanbel "kadının namaz kılarken tırnağı dahi görülmemeli," demiştir. İmam Mâlik ise kadının saçı veya ayakları açılırsa vakit çıkmamışsa namazını iade edeceğini söylemiştir. Ashâbu rey saçın, baldırın, karnın bölümlerinden dörtte birinden fazlası açılmadığı sürece namaz bozulmaz demektedir. ${ }^{58}$ Aynı zamanda Hanefî mezhebi bu rivayetten kadının namazında derli-toplu olmasının istendiğini anlamış ve kadınların namaz kılma şekilleri ile ilgili açlklamalarında delil olarak konuyla ilgili Hz. Peygamber'den (s.a.s.) gelen rivayetlere ve "kadın avrettir" rivayetine dayanmışlardır. ${ }^{59} \mathrm{Bu}$ rivayet

\footnotetext{
55 Nevevî, el-Mecmû, 3/526.

56 Tirmizî, "Radâ", 18.

57 Ebû Bekr Ahmed el-Bezzâr, el-Bahrü'z-Zehhâr, thk. Mahfuzu'r-Rahman Zeynullah, vd. (Medine: Mektebetü'l-Ulûm, 2009), 5/427.

58 Muhammed b. Furek, Müşkilü'l-Hadis ve Beyânühû, thk. M. Muhammed Ali (Beyrut: Âlimü'l-Kütüb, 1985), 374; Ebû Süleyman el-Hattâbî, Me'âlimü's-Sünen (Haleb: el- Matbaatü'l-İlmiyye, 1932), 1/180.

${ }^{59}$ Serahsî, el-Mebsût, $1 / 23$.
} 
diğer mezheplerin kaynaklarında da görülmektedir. ${ }^{60}$ Dört mezhep kadının namazı ile ilgili hususlarda görüş belirtirken أستر هَّا "(bu) onun için tesettüre daha uygundur" ifadesini zikretmişlerdir. ${ }^{61}$ Yani mezheplerin kadının namaz kılış şekline dair görüşleri kadının daha tesettürlü olması gerektiği ile ifade edilmiştir.

"Kadın için tesettüre daha uygundur" ifadesinin kadının daha derli toplu durmasına işaret ettiği unutulmamalıdır. Dolayısıyla bu ifade tesettür emrini daha iyi sağlamak adına ta'dîl-i erkândan taviz vermek olarak anlaşılmamalıdır.

Bu hususta kadınlar kıyamda ellerini bağlarken, kendilerine mahsus bir emrin günümüze ulaşmamış olması sebebiyle Hz. Peygamber'den gelen uygulamalardan birine (sağ elini sol eli üzerine koyması, sağ eliyle sol el bileğini kavraması, sağ elini sol kolun üzerine koyması, ellerini gögüs, göbek altı ve her ikisi arasına yerleștirmesi) tâbi olmaktadırlar. Mezheplerin kadınların elleri bağlamasına dair görüşleri de bu uygulamalardan birine dayanmaktadır.

\section{Rükû}

\subsection{Hz. Peygamber'in (s.a.s.) Rükû Yapma Biçimi}

Sözlükte "eğilmek" anlamlarına gelen rükû, namazın rükünlerinden olup kıraatin tamamlanmasıyla baş ve sırt düz olacak şekilde eğilmeyi ifade eder ve ellerle diz kapaklarını tutarak uygulanır. Rükûun nasıl yapılacağına dair bilgiler Hz. Peygamber'in söz ve fiillerine dayanır. ${ }^{62}$ Bu başlık altında Hz. Peygamber'in (s.a.s.) nasıl rükû ettiği ile ilgili rivayetler ele alınacaktır.

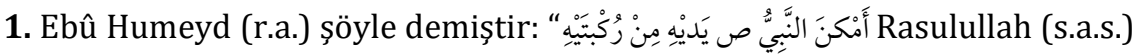
(rükûda) ellerini dizleri üzerine iyice yerleştirirdi"63

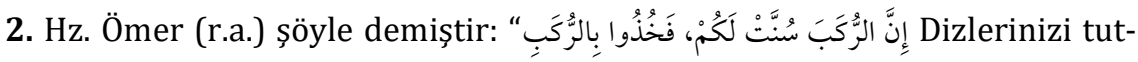
mak size sünnet kılınmıştır. Öyleyse (rükûda) dizlerinizi iyice kavrayın."64

3. Muhammed b. Amr el-Âmirî'den: Rasulullah'ın (s.a.s.) ashabının (olduğu) bir meclisteydim. Rasulullah'ın namazından bahsediyorlardı. Ebû Humeyd (r.a.)

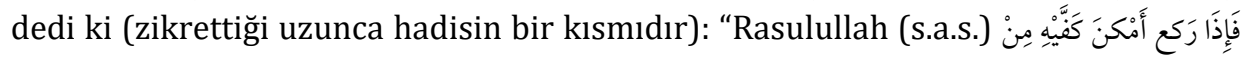
rülkûa vardığında avuçlarıyla diz kapaklarını iyice kavrar, parmaklarının arasını açar, başını aşağı eğmeden ve yanağını (çevirmeden) sırtını dümdüz yapardı."65

4. Abbas b. Sehl şöyle demiştir: Ebû Humeyd, Ebû Üseyd, İbn Sa'd ve İbn

\footnotetext{
60 İbnü'l-Müneccâ, el-Mümti' (Mekke: Mektebetü'l-Esedî, 2003), 1/377.

61 İbnü'l-Müneccâ, el-Mümti', 1/377; Kevkeb 'Ubeyd el-Hâcce, Fıkhu'l-İbâdât ale'l-Mezhebi'l-Mâlikî (Suriye: Matbaatü'l-İnşâ', 1986), 163; Şîrâzî, el-Mühezzeb (Beyrut: Dâru'l-Kütübi'l-İlmiyye ts.), 1/143.

62 İbn Manzur, Lisânü'l-'Arab, 8/133; Nihat Dalgın, "Rükû", Türkiye Diyanet Vakfı Íslam Ansiklopedisi (İstanbul: TDV Yayınları, 2008), 35/286.

${ }^{63}$ Buhârî, "Ezân”, 118.

64 Tirmizî, "Salât", 77.

65 Ebû Dâvûd, "Salât”, 116.
} 
Mesleme buluştuklarında Rasulullah'ın namazından bahsettiler. Ebû Humeyd dedi

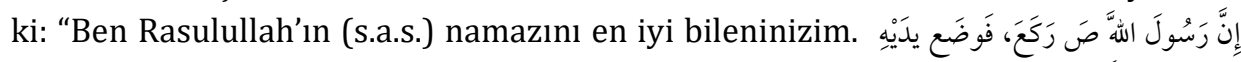
Rasulullah (s.a.s.) rükûa vardığında dizlerini avuçlar gibi ellerini dizleri üzerine koyardı ve (kollarını) gererek yanlarından aralardı (uzaklaştırırdı). ${ }^{66}$

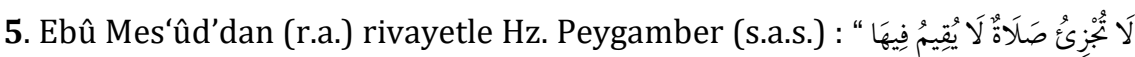

Rükû ve secde yaparken belini doğrultmayanın (düz tutmayanın) namazı yeterli olmaz" buyurmuştur ${ }^{67}$

Yukarıdaki hadislerin bize sunduğu çerçeve içerisinde Hz. Peygamber'in (s.a.s.) rükûu şöyledir: Elleri ile dizlerini iyice kavrar, parmaklarının arasını açık tutar, sırtı dümdüz olacak şekilde eğilir, kollarını yanlarından uzaklaştırır, rükûunu tamamladıktan sonra omurlar yerine gelecek şekilde dimdik ayakta dururdu.

Rükûun yapılışı hakkında mezhepler arasında büyük bir ihtilafın olduğu söylenemez. Onların ihtilaf ettikleri husus rükûun asgari miktarı, farzlığı- vacipliği, elleri tam olarak dizlere ya da dizlerin az yukarısına koyma ve parmakların arasını açma ya da kendi halinde bırakma konularındadır. 68

\subsection{Kadınların Rükû Yapma Biçimi}

Kadınların nasıl rükû edeceklerine dair merfu ya da mevkuf bir rivayet tespit edemedik. Ancak ümmetin âlimlerinin - özellikle namaz gibi temel bir ibadet hususunda - hata üzere ittifak etmelerinin düşünülemeyeceği göz önünde bulundurularak böyle bir amelin naslarda aslının olmadığının söylenemeyeceği kanaatindeyiz. Bu sebeple kadınların farklı şekilde rükû etmeleri ile ilgili bize bir rivayet ulaşmazken amel ulaşmış olabilir düşüncesi zihnimizin bir köșesinde yerini korumaktadır.

Burada kadının rükûuna dair tespit edilebildiği kadarıyla en eski görüş Atâ b. Ebî Rebâh'a ö. (114/732) aittir. Bu görüş konuyla ilgili ayrımdan ilk kez bahsetmesi yönüyle önemlidir.

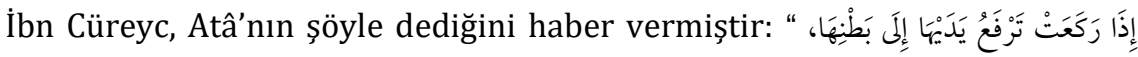

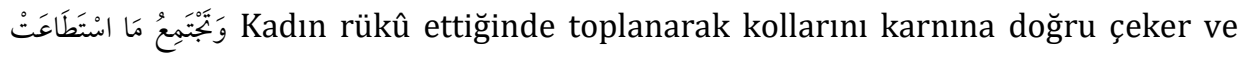

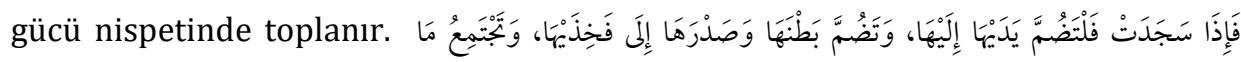
Secdeye gittiğinde kollarını kendine doğru çeksin. Karnını ve göğsünü uyluklarına doğru çeksin ve gücü yettiğince toplansın."69

Nassın bulunmadığı konularda kendi ictihadıyla hükmettiği, ancak mesnet-

\footnotetext{
66 Tirmizî, "Salât", 67.

67 Tirmizî, "Salât", 81.

68 Nihat Dalgın, "Rükû", 35/286.

${ }^{69}$ Abdürrezzâk, el-Musannef, 3/137.
} 
siz reye de karşı çıktığı söylenen ve Hicaz fikıh ekolünün teșekkülünde önemli bir role sahip Atâ'nın ${ }^{70}$ zikredilen görüşünü neye dayandırdığı ile ilgili bir bilgiye ulaşamadık. Bu maktu rivayet haricinde kadının rükûu hakkında bir delil tespit edebilmiş değiliz.

Mâlikî ve Şâfîi mezhebinde kadın rükû ederken kollarını yanlarına yapıștırmalıdır. Tespit edilebildiği kadarıyla iki mezhep de kadının rükû șekli ile ilgili başka bir açıklamada bulunmamıștır. ${ }^{71}$ Hanbelî mezhebine göre kadının rükû ve secdede kendini toplaması tesettüre daha uygundur. ${ }^{72}$ Hanefî mezhebine göre kadınlar rükû ederken hafifçe eğilir, parmaklarını ayırmayıp birleştirir ve dizleri üzerine koyar, dizlerine doğru eğilir pazularını içe doğru toplar. Çünkü bu durum onlar için tesettüre daha uygundur. ${ }^{73}$ Kadınlara mahsus yapılan bu tarifin, mezhebin rükû emrine yaklaşımının açıklanmasından sonra daha anlaşılır hale geleceği kanaatindeyiz.

Rükûun ne kadar bir eğilmeyle tamam olacağı konusunda Hanefî mezhebinde tarefeyn (Ebû Hanîfe ve İmam Muhammed) ayette mutlak olarak rükû yapılması emredildiğinden rükû denilebilecek şekilde eğilmeyle bu emrin yerine getirildiği görüşündedirler. Rükû yaparken bir süre beklemeye "tume'nîne”, rükûdan doğrulduktan sonra uzuvlar sakinleşinceye kadar bir müddet ayakta durmaya "kavme" denir. Tume'nîne tarafeyne göre farz değil, vaciptir. (İmam Ebû Yûsuf'a göre ise tuma'nîne farzdır.) Rükûa yakın bir eğilme ile bu rükün yerine getirilmiş olurken, kıyama yakın bir eğilme rükû sayılmamaktadır. Bu noktadan hareketle kadınlar rükûa yakın bir eğiliş gerçekleștirdiklerinde rükû yerine gelmiş olacaktır. Ancak tarafeyn namazın en güzel şekilde eda edilebilmesi için tuma'nînenin gerekli olduğu görüşündedir. ${ }^{74}$ Mezhebin ayetteki rükû emrinin keyfiyetini tespitte ameli önceleyerek bir tarife gittiği de unutulmamalıdır.

Burada Hanefî mezhebinin yaklaşımının daha iyi anlaşılabilmesi için amel olgusuna açıklık getirmek faydalı olacaktır. Mâlikî mezhebinin "amelu ehl-i Medine" temelli sünnet anlayışının bir benzeri Hanefî mezhebinde "amelu/hadisu ehl-i Kûfe" (Kûfe ehlinin hadisi/ameli) olarak kendini göstermektedir. Nitekim bu anlayış çerçevesinde bir konuda çok kuvvetli deliller sunulsa da Hanefî mezhebi için Hz. Ömer, Hz. Ali, İbn Mes'ûd ve onların ekolünü sürdüren âlimlerin ortaya koydu-

70 İsmail Cerrahoğlu, “Atâ b. Ebû Rebâh”, Türkiye Diyanet Vakfı İslam Ansiklopedisi (İstanbul: TDV Yayınları, 1991), 4/35.

71 'Ubeyd el-Hâcce, Flkhu'l-İbâdât ale'l-Mezhebi'l-Mâlikî, 163; eş-Şîrâzî, el-Mühezzeb, 1/143; Soner Duman, Ayet ve Hadislerle Şâfiî İbadetler İlmihali (İstanbul: Miraç Yayınları, 2013), 293. Sayfada şu cümleye yer verilmiștir: Kadınlar, rükû ve secdede karınları ile bacaklarını birbirine bitiştirir. Bu ihtiyata daha uygundur.

72 İbnü'l-Müneccâ, el-Mümti', 1/377.

73 İbn Âbidîn, Reddü'l-Muhtar, 1/494; Bu durum ilmihal kitaplarında genellikle şu şekilde ifade edilmiştir: Kadınlar ellerini dizleri üzere koyar ve dizlerini bükük, arkalarını meyilli bulundururlar. Bilmen, İslam İlmihali, 122; Lütfi Şentürk-Seyfettin Yazıcı, İslam İlmihali, 132; İlmihal İman ve Íbadetler, 254. Ayrıca "kadınlar rükûda tam eğilmezler" şeklinde açılamalar da görülmektedir: Hasan Çalıșkan, Hanımlara İlmihal, 203.

${ }^{74}$ Nihat Dalgın, "Rükû", 35/286; Burhânuddin el-Mergīnânî, el-Muhîtü'l-Burhânî, thk. A. Sami el-Cündî (Beyrut: Dârü'l-Kütübi'l-İlmiyye, 2004), 1/336-337. 
ğu deliller öncelik arzetmektedir. ${ }^{75}$

\section{Secde}

\subsection{Hz. Peygamber'in (s.a.s.) Secde Yapma Şekli}

Secde, sözlükte "boyun eğmek, alnı tevazu ile yere koymak" anlamlarına gelir. Namazın rükünlerinden olan secde rükûdan sonra alın, burun, iki avuç, iki diz ve iki ayak parmak uçlarının yere temas etmesiyle gerçekleşir. ${ }^{76}$

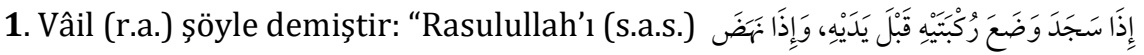
secde ederken ellerinden önce dizlerini koyduğunu, secdeden doğrulurken de dizlerinden önce ellerini kaldırdığını gördüm."77

$\mathrm{Bu}$ rivayet Hz. Peygamber'in (s.a.s.) secdeye giderken öncelikle dizlerini, daha sonra da ellerini yere koyduğunu, secdeden kalkerken de tam tersini tatbik ettiğini haber vermektedir. Secdeye giderken ellerden önce dizlerin konması ile ilgili rivayet Ebû Hureyre'den de gelmektedir. ${ }^{78}$ Ancak Ebû Hureyre'den (r.a.) secdeye giderken ellerin dizlerden önce konması gerektiğine dair de rivayet gelmiștir. ${ }^{79}$

2. Ebû İshak (r.a.) şöyle demiştir: "Berâ b. Âzib'e "Rasulullah secde ettiğinde

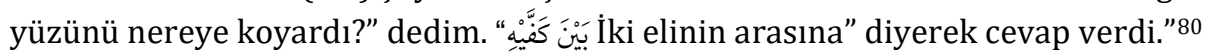

3. Vâil (r.a.) şöyle demiştir: "Medine’ye geldiğimde kendi kendime 'Mutlaka Hz. Peygamber'in (s.a.s.) namazına bakacağım' dedim. Tekbir alıp ellerini bașparmakları kulakları yakınına gelecek şekilde kaldırdığını gördüm. Rükû edeceğinde tekbir getirdi ve ellerini kaldırdı. Sonra rükûdan başını kaldırdı ve "Semi'allâhu

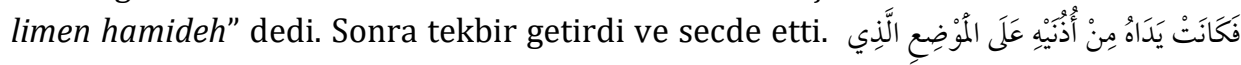

75 Taha Çelik, Hadis Mezhep İhtilaf (Beyhakî’nin Tahâvi'ye İtirazları), (Konya: Palet Yayınları, 2019 ), 322.

76 İbn Manzur, Lisânüll-'Arab, 3/204; Nihat Dalgın, "Secde”, Türkiye Diyanet Vakfı Íslam Ansiklopedisi (İstanbul: TDV Yayınları, 2009), 36/271.

77 Ebû Dâvûd, "Salât", 145.

78 İbn Ebî Şeybe, el-Musannef, 1/235.

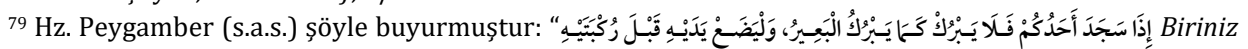
secdeye giderken devenin çöktüğü gibi çökmesin. Dizlerden önce ellerini yere koysun” Ebû Dâvûd, "Salât", 145. Ebû Hureyre rivayeti için Buhârî, Tirmizî ve Dârekutnî ö. (385/995) illetli demişlerdir. Tirmizî rivayetin Ebü'z-Zinâd'dan başka bir tarikten gelmediğini ve hadisin garib olduğunu söylemiştir. Tehânevî, I'lâü's-Sünen, 3/35. Bu konudaki rivayetler incelendiğinde Vâil'den (r.a.) gelen rivayetlerde bir farklılık olmadığı ancak Ebû Hureyre'den gelen rivayetlerin birbiri ile çeliştiği görülmektedir. Dolayısıyla Vâil'in (r.a.) rivayeti sabit olur. Ayrıca Ebû Hureyre'den gelen farklı rivayetin hükmünün mensuh olduğu görüşü vardır. Bununla birlikte, âlimler devenin çökerken önce ön ayaklarını, sonra arka ayaklarını yere koyması sebebiyle, Ebû Hureyre rivayetinin yasaklanan fiille çeliştiğini söylemektedirler. bk. Tahâvî, Şerhu Meâni'l-Âsâr, 1: 254; Tehânevî, İlâü's-Sünen, 3: 36. Devenin çöküşü incelendiğinde önce ön ayaklarını sonra arka ayaklarını yere koyduğu görülecektir. Devenin ön ayakları insanın elleri, devenin arka ayakları ise insanın dizleri mesabesindedir. Yani "devenin çöküşü gibi çökmesin" sözü ile anlatılmak istenen kişinin önce ellerini değil dizlerini koyması gerektiğidir.

80 Tirmizî, “Salât”, 87. 
Secdede elleri kıbleye yönelmiş halde, kulakları hizasındaydı." 81

4. Ebû Humeyd es-Sâidî (r.a.) şöyle demiştir: "Rasulullah (s.a.s.) secde ederken alın ve burnunu iyice yere koyar, وَنَحَّى يدَيْهِ عَنْ جَنْبِيْ "kollarını yanlarından uzaklaştırır, ellerini omuzları hizasına (paralel gelecek şekilde) koyardı." 82

Secdede ellerin kulak ya da omuz hizasına konabileceğini haber veren bu rivayetler için cem ve teliften söz etmenin mümkün olduğunu, Hz. Peygamber'in her iki uygulamayı da muhtelif zamanlarda yapmış olabileceğini söyleyen âlimler olmuştur. Bununla birlikte ellerin omuzlar hizasında yere konmasının yaşlılık ve hastalık gibi özür haline mahsus bir durum olduğu yorumunu yapanlar da vardır. ${ }^{83}$

Mezheplerin bu konudaki görüşleri ise tekbir alırken elleri kaldırma konusundaki görüşleriyle uyumludur. Şöyle ki; tekbir alırken ellerin kulaklara kadar kaldırılacağı hadisiyle amel edenler, secde ederken de ellerin kulak hizasında yere konulacağı hadisine uymaktadırlar. Tekbir alırken ellerin omuz hizasına kadar kaldırılacağını kabul edenler ise secde esnasında da ellerini omuzları hizasında yere koyarlar. ${ }^{84}$

5. Berâ'dan (r.a.) rivayetle Hz. Peygamber (s.a.s.): “Secde ettiğinde فَضَعْ كَفََّْكَ avuçlarını yere koy, dirseklerini kaldır" buyurmuştur. ${ }^{85}$

Hadisteki "dirseklerini kaldır" emrinden, hem dirseklerin yerden kaldırılması, hem de vücuttan uzaklaştırıp yanlara (sağa ve sola) doğru açılması anlaşılır. ${ }^{86}$ Konuyla ilgili rivayetlerde, dirseklerin vücuttan uzaklaştırılması gerektiğinin vurgulanmasının yanı sıra, Hz. Peygamber (s.a.s.) bu konuda zorlananlara "kollarını dizlerine dayayabilecekleri" şeklinde bir ruhsat vermiştir.

Ebû Hureyre (r.a.) şöyle demiştir: “Rasulullah'ın (s.a.s.) ashabı secde ederken elleri yanlardan, karnı dizlerden uzaklaştırmanın zorluğundan yakındılar da: 'Dirsekleri dizlere dayayarak rahatlayın,' buyurdu."87

Kolları dizlere dayayabilme ruhsatının yanlış anlaşılmaması için şu hadisi zikretmek faydalı olacaktır: Enes'ten (r.a.) nakledildiğine göre Rasulullah (s.a.s.)

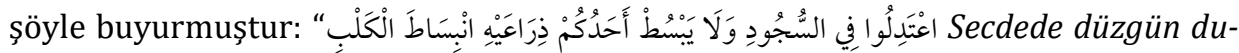
runuz. Biriniz kollarını köpeğin yaydığı gibi yere yaymasın."88

6. İbn Abbas'tan (r.a.) rivayetle Rasulullah (s.a.s.): “Ben yedi kemik; alın, burun, (yüz) iki el, iki diz ve iki ayak üzere secde edip saçımı ve elbisemi toplamamakla emrolundum" buyurmuştur. ${ }^{89}$

\footnotetext{
${ }^{81}$ Nesâî, "Tatbîk", 48.

82 Tirmizî, "Salât", 86.

${ }^{83}$ Kemaleddin İbnü'l- Hümam, Fethu'l-Kadir (b.y.: Dâru'l-Fikr, ts.), 1/303; Serahsî, el-Mebsût, 1/22.

${ }^{84}$ Ebû Cafer et-Tahavî, Şerhu Meâni'l-Âsâr (Beyrut: Âlimü'l-Kütüb, 1994), 1/257.

85 Müslim, "Salât", 494.

${ }^{86}$ Nevevî, el-Minhâc, 4/209.

${ }^{87}$ Tirmizî, "Salât", 96. Tirmizi hadisin "garib" olduğunu söylemiş ve bu rivayetin sadece Ebû Sâlih'in Ebû Hureyre'den (r.a.) nakliyle bilindiğini haber vermiştir.

88 Müslim, "Salât", 493.

${ }^{89}$ Müslim, "Salât", 490.
} 
Sonuç olarak secdenin tatbiki hususunda secdeye giderken yere ellerden önce dizleri koymak, yüzün iki elin arasında olması, secde esnasında ellerin kulaklarla ya da omuzlarla aynı hizada olması, dirseklerin bögürrlerden uzaklaştırılmış olması, kolların yere yayılmaması ve secdede iken sayılan yedi organın yerle temas etmesi emredilmiştir.

\subsection{Kadınların Secde Yapma Șekline Dair Rivayetler}

Bu başlık altında kadınların secdesine dair rivayetler incelenecektir.

1. İbn Ömer'den (r.a.) rivayetle Hz. Peygamber (s.a.s.) şöyle buyurmuştur:

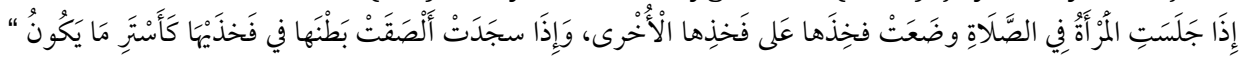
" Kadın namazda oturduğunda, bir uyluğunu diğer uyluğu üzere koyar. Secde ettiğinde, olabildiğince tesettüre riayet ederek karnını uyluğuna yapıștırır. Allah o kadına bakar ve: 'Ey meleklerim! Sizi şahit tutuyorum ki onu bağışladım' buyurur."90

Târihu İsfehan'da rivayetin senedi şöyledir: Ahmed b. Ubeydullah b. Ahmed b. Said> Muhammed b. Abdirrahman er-Erzünânî ö. (322/933)> Ebû Muhammed Ubeyd b. Musa es-Serahsî > Muhammed b. Kâsım el-Belhî (tahmini ö.240/854)> Ebû Mutî‘ el-Belhî ö. (199/814)> Ömer b. Zer ö. (153/770)> Mücâhid b. Cebr ö. (103/721)> Abdullah b. Ömer ö. (73/692)

Ebû Mutî‘ el-Belhî ö. (199/814) için İbn Mâîn ö. (233/848) ve Buhârî "zayıf” demiştir. Cehmî ve Mürcî olduğu iddia edilmiştir. ${ }^{91}$

Tespit edilebildiği kadarıyla Muhammed b. Kâsım el-Belhî et-Taykânî'nin muasırları takriben (240/854) yıllarında vefat etmiştir. Kendisinden hadis aldığı Abdülazîz b. Hâlid'in muasırları da 200'lü yıllarda vefat etmiştir. Dârekutnî "zayıf" olduğunu söylemiş, Cûzekânî ö. (543/1148) "hadis uydururdu" demiştir. ${ }^{92}$ Ebû Muhammed Ubeyd b. Musa es-Serahsî hakkında bir bilgiye ulaşılamamıştır.

Ahmed b. Ubeydullah b. Ahmed b. Said Ebü'l-Hasen el-Kassâr el-Mümenna'. 380/990 yılında vefat eden Selm b. I'sâm'dan hadis almıștır. ${ }^{93}$ Zikredilen hususlar dışında hakkında bir bilgi tespit edilememiştir. Diğer raviler ise sikadır.

Beyhakî̀nin Sünen'inde yer alan bu rivayetin senedi tam olarak Ebû Nuaym'ın ö. (430/1038) Tarihu İsfahân'ında yer almaktadır. Biz de yukarıda, oradaki senedi verdik. Tespit edilebildiği kadarıyla bu rivayetin başka bir tariki bulunmamaktadır. Hadisin senedindeki Ebû Mutî‘ el-Belhî'nin zayıf bir ravi olması, Muhammed b. Kâsım el-Belhî'nin de zayıf ve yalancı olması sebebiyle bu hadisin çok zayıf olduğunu söyleyebiliriz. Nitekim Beyhakî de bu rivayetin zayıf olduğunu

\footnotetext{
90 Ebû Nuaym el-İsfehânî, Târihu İsfehan, thk. S. Kisrevî Hasan (Beyrut: Dârû'l-Kütübi'l-İlmiyye, 1990), 1/200; Beyhakî, es-Sünenül-Kübrâ, 2/315.

91 Zehebî, et-Târîh, 4/1097; İbn Hacer, Lisânü'l-Mîzân, thk. Abdulfettah Ebû Gudde (Beyrut: Dârü'lBeşâiri'l-İslâmiyye, 2002), 3/246; Mehmet Şener, "Ebû Mutî‘ el-Belhî”, Türkiye Diyanet Vakfi İslâm Ansiklopedisi (İstanbul: TDV Yayınları,1994), 10/194-195.

92 İbn Hacer, Lisânü'l-Mîzân, 7/444 ve 451.

${ }^{93}$ Ebû Nuaym, Târihu İsfehan, 1/200.
} 
kaydetmiştir.

2. Yezîd b. Ebû Habîb, Rasulullah'ın (s.a.s.) namaz kılan iki kadına rastladığ1-

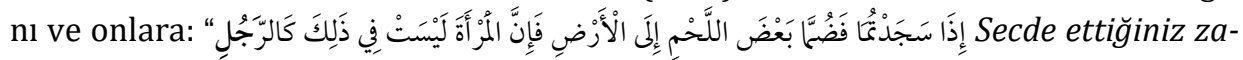
man vücudunuzun bir kısmı yere değsin. Çünkü bu konuda kadın erkek gibi değildir" dediğini haber vermiştir. ${ }^{94}$

Ebû Dâvud'un ö. (275/889) Merâsil'indeki rivayetin isnadı şöyledir: Süleyman b. Dâvûd ö. (256/869) > İbn Vehb ö. (197/812) > Hayve b. Şurayh ö. (158/775)> Sâlim b. Gaylân ö. (151/768)> Yezîd b. Ebû Habîb ö. (128/745)

Rivayetin senedindeki Sâlim b. Gaylân "sadûk"95, diğer raviler ise "sika"dır. ${ }^{96}$

$\mathrm{Bu}$ hadis kadınların secdesini tarif etmektedir. İsnad zincirindeki raviler incelendiğinde metruk bir ravi görülmemektedir. Ancak hadis tâbiîden Yezîd b. Ebû Habîb'in doğrudan Hz. Peygamber'den rivayet etmesi sebebiyle mürseldir. Mürsel hadis hakkında farklı görüşler olmakla birlikte, zayıf kabul edilir.

3. Ebû Saîd el-Hudrî'den (r.a.) rivayetle Hz. Peygamber (s.a.s.): "Erkekler için en hayırlı olan saf ilk saf, kadınlar için en hayırlı olan saf ise son saftır" buyurmuştur.

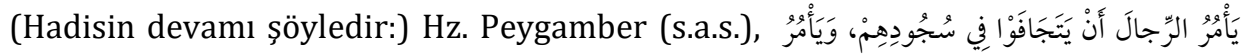
erkeklerin secdede kollarını böğürlerinden ayırmalarını, kadınların ise kollarını toplamasını emrederdi. Erkeklerin teşehhüdde sol ayağını yayıp sağ ayağını dikerek oturmalarını söylerken, kadınların ise bağdaş kurarak oturmalarını emrederdi. ${ }^{97}$

es-Sünenü'l-Kübrâ'da rivayetin isnadı şöyledir: Hâkim ö. (405/1014)> Ebu'lAbbas Muhammed b. Yâkub en-Nîsâbûrî ö. (346/957)> el-Abbas b. Velîd b. Mezyed el-Beyrûtî ö. (271/884)> Muhammed b. Şuayb ö. (200/815)> Abdurrahman b. Süleym(an) ${ }^{98}$ ö. (190/805)> Atâ b. Aclân ö. (131-140/748-757)> Ebû Nadra elAbdî ö. (109/727)> Ebû Saîd el-Hudrî ö. (74/694)

Atâ için Yahya b. Maîn: "sika değil" demiştir. Buhârî "münkeru'l-hadis" olduğunu söylemiştir. ${ }^{99}$ Abdurrahman b. Süleyman b. Ebî’l-Cevn el-Ansî ed-Dımeșkî için Ebû Hâtim: "hadisi yazılır ama rivayetleri delil olmaz" demiştir. Ebû Dâvûd "zayıf" olduğunu söylemiștir. İbn Mâce ö. (273/887) ondan sadece bir hadis rivayet etmiştir. ${ }^{100}$ Sika olmayan Atâ b. Aclân ve zayıf kabul edilen Abdurrahman haricinde diğer

${ }^{94}$ Ebû Dâvûd, el-Merâsil, thk. Şuayb Arnavut (Beyrut: Müessetü'r-Risâle, 1408/1998), 117, aynı lafizla Beyhakî'nin es-Sünenü'l-Kübrâ'sında da geçmektedir. 2/315.

${ }^{95}$ Mizzî, Tehzîbü'l-Kemâl, 10/168-172; Zehebî, et-Târîh, 3/870; “ a.mlf.”, Mi'zânü'l-İ'tidâl, 2/113.

${ }^{96}$ Süleyman b. Dâvûd için bk. Mizzî, Tehzîbü'l-Kemâl, 9/86-87; İbn Vehb için bk. Zehebî, es-Siyer, 9/226; Hayve için bk. Zehebî, es-Siyer, 6/405; Yezîd için bk. İbn Hacer, Tehzîbü't-Tehzîb, 11/319.

97 Beyhakî, es-Sünenü'l-Kübrâ, 2/314; tercüme için, Beyhakî, es-Sünenü'l-Kebîr, çev. Hüseyin Yıldız, vd. (İstanbul: Ocak Yayıncılık, 2016), 1/224.

${ }_{98}$ Abdurrahmen b. Süleym hakkında bilgi veren tabakat ve teracim kitapları ondan Süleyman olarak da bahsetmektedir. bk. Mizzî, Tehzîbü'l-Kemâl, 17/152-154.

${ }^{99}$ Mizzî, Tehzîbü'l-Kemâl, 20/94-97; Zehebî, et-Târîh, 3/700. Buhârî bu cerh ifadesini kendisinden hadis rivayet etmenin helal olmadığı raviler için kullanmaktadır. bk. Abdullah Aydınlı, Hadis Istılahları Sözlüğü (İstanbul: Timaș Yayınları, 1987), 112.

100 Mizzî, Tehzîbü'l-Kemâl, 17/152-154; Zehebî, es-Siyer, 10/186-187. 
raviler sikadır. ${ }^{101}$ Beyhakî bu rivayetin zayıf olduğunu kaydetmiştir.

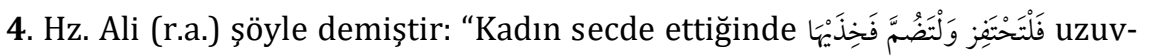
ları üzere toplansın (ihtifaz) ve uyluklarını bitiştirsin."102

İbn Ebî Şeybe ö. (235/849) rivayetin isnadını şöyle vermiştir: Ebü'l-Ahvas (ö.179/795)> Ebû İshak es-Sebîi ö. (129/746)> Hâris b. el-A'ver ö. (64-71/683692)> Hz. Ali

Şấbî ö. (104/722) Hâris'in kendisine hadis rivayet etiğini fakat onun yalancı olduğunu söylemiştir. İbn Maîn ise "sika" olduğunu söylemiştir. İbn Hacer hadislerinin "zayıf" olduğundan söz etmiştir. ${ }^{103}$ Diğer raviler sikadır. ${ }^{104}$ Mevkuf olan bu rivayetin senedindeki Hâris için farklı görüşler olması sebebiyle rivayetin zayıf olduğu söylenebilir.

Abdürrezzâk'ın ö. (211/826) Musannef'inde rivayetin isnadı şöyledir: İsrâil b. Yunus es-Sebîl ö. (160/776)> Ebû İshak es-Sebîi ö. (129/746)> Hâris b. el-A'ver ö. (64-71/683-692)> Hz. Ali

Abdürrezzâk'ın Musannefinde bu rivayeti İsrâil, Ebû İshak'tan nakletmiştir.

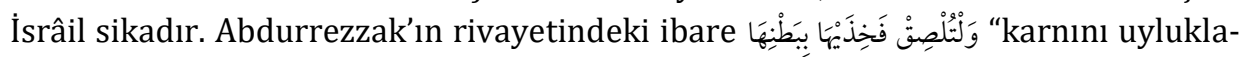
rına bitiștirsin" șeklindedir. ${ }^{105}$

Beyhakî'nin Sünen'inde rivayetin isnadı şöyledir: Hâkim ö. (405/1014)> Ebubekir b. İshak el-Fakîh ö. (342/953)> el-Hasen b. Ali b. Ziyâd ö. (291/903)> Said b. Mansur ö. (227/841)> Ebü'l-Ahvas ö. (179/795)> Ebû İshak es-Sebîî ö. (129/746)> Hâris b. el-A'ver ö. (64-71/683-692)> Hz. Ali

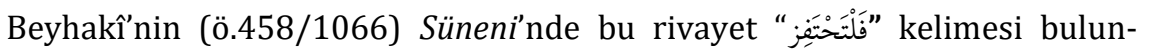
maksızın zikredilmiştir. Ravi Ebubekir b. İshak için Buhârî "hadisi münkerdir" demiştir. ${ }^{106}$ Buhârî'nin bu ifadesi șiddetli cerhtir. ${ }^{107}$

İbn Ebî Şeybe'nin kitabında tâbiînden Bükeyr b. Abdullah b. el-Eşec'ten şu rivayet nakledilir: İbn Abbas'a kadının namazı hakkında sorulmuş, o da şöyle de-

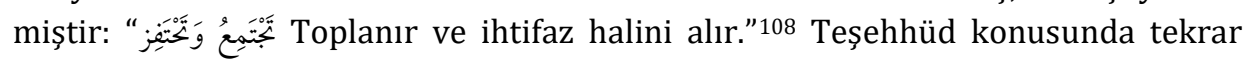
zikredileceği üzere ihtifaz kelimesini Ali el-Kârî ö. (1014/1605) "uzuvlarını birleştirip teverrük üzere otururlar" şeklinde açıklamıştır. ${ }^{109}$

101 Ebü'l-Abbas Muhammed için bk. Kandemir, M. Yașar, “Esam, Ebü'l-Abbas”, Türkiye Diyanet Vakfı Íslam Ansiklopedisi (İstanbul: TDV Yayınları, 1995), 11/ 355; el-Abbas b. Velîd için bk. Mizzî, Tehzîbü'l-Kemâl, 14/255-258; Muhammed b. Şuayb için bk. Mizzî, Tehzîbü'l-Kemâl, 25/ 370-375; Ebû Nadra için bk. Zehebî, es-Siyer, 6/ 529-530.

102 İbn Ebî Şeybe, el-Musannef, 1/241; Abdurrezzak, el-Musannef, 3/138; Beyhakî, es-Sünenü'l-Kübrâ, $2 / 314$.

103 Mizzî, Tehzîbü'l-Kemâl, 5/244-246; İbn Hacer, Tehzîbü't-Tehzîb, 2/146.

${ }^{104}$ Ebü'l-Ahvas için bk. Zehebî, es-Siyer, 8/ 281-283; Ebû İshak için bk. İbn Hacer, Takrîbü't-Tehzîb, 1/ 423.

105 İbn Hacer, Tehzîbü't-Tehzîb, 1/263.

106 Zehebî, el-Kâşsif, thk. Muhammed Avvame (Cidde: Dâru'l-Kıbleli's-Sekâfeti'l-İslâmiyye,1992), 2/410.

${ }_{107}$ Abdullah Aydınlı, Hadis Istılahları Sözlüğü (İstanbul: Timaş Yayınları, 1987), 112.

108 İbn Ebî Şeybe, el-Musannef, 2/241.

109 Alî el-Kârî, Şerhu Müsnedi Ebî Hanîfe, thk. Halil Muhyiddin (Beyrut: Dâru'l-Kütübi'l-İlmiyye, 1985), 
Kadınların secdesine dair incelenen rivayetlerin ricâl bakımından en sağlamı, ikinci olarak zikredilen Yezîd b. Ebû Habîb'den gelen mürsel hadistir. Onun sika olduğundan söz edilmişti. Söz konusu rivayetin tek kusuru mürsel olmasıdır. Mürselin delilliği konusunda farklı görüşler mevcuttur. Derece bakımından Yezîd hadisini, dördüncü sırada zikredilen Hz. Ali'den gelen mevkuf rivayet takip etmektedir. Bu mevkuf rivayetin senedindeki Hâris'in hadislerinin zayıf olduğu söylenmiştir. Kadınların secdesi ile ilgili merfu olan iki rivayete gelince; Beyhakî kitabında bunları zikredip "delil olmayan iki zayıf hadistir," demiştir. ${ }^{110}$

$\mathrm{Bu}$ rivayetlerde kadının secdede daha derli-toplu durması istenmektedir. Ancak yaygın şekilde karşılaşılan bir durum olan kadınların secde ederken kolları yere yapıştırmaları derli toplu olmaya dahil değildir. ${ }^{111}$ Nitekim Hz. Peygamber (s.a.s.) şöyle buyurmuştur: "Secdede düzgün durunuz. Biriniz kollarını köpeğin yaydığı gibi yere yaymasın."112 Kolları yaymak hem kadın hem erkek için yasaklanmıştır. Kolların durumu üçüncü olarak zikredilen rivayette emredildiği şekilde; böğürlere yakın olmalıdır.

Mezheplerin konuyla ilgili görüşlerine gelince; Hanefî mezhebi kadının secdesi ile ilgili yukarıda zikredilen rivayetlerden çıkan genel manaya uygun olarak karnını dizlerine çekip kollarını yanlarına yapıştırmaları gerektiğini söyler. Hz. Ali'den gelen "Kadın secde ettiğinde uzuvları üzere toplansın ve uyluklarını bitiştirsin" rivayetini delil olarak gösterir. ${ }^{113}$ Şâfiî ve Hanbelî mezhebindeki görüş de kadının secdede derli toplu durması yönündedir. ${ }^{114}$

\section{Teşehhüd}

\subsection{Hz. Peygamber'in (s.a.s.) Teşehhüdde Oturuş Biçimi}

Teșehhüd sözlükte "şahitlik istemek, şehadet getirmek, tahiyyata oturmak" anlamlarına gelir. Terim olarak da "namazda ka'dede tahıyyatı okumayı" ifade eder. Bu oturuş üç ve dört rekâtlı namazların ilk iki rek'atından sonra olursa ka'dei ûlâ, selamdan önceki son oturuş ise ka'de-i âhire olarak isimlendirilir. İlk iki rekattan sonra oturma için celse, son oturuşa ka'de denmesi yaygındır. ${ }^{115}$

1. Daha önce de zikredilen Ebû Humeyd hadisinde Ebû Humeyd

\footnotetext{
$1 / 191$.

${ }^{110}$ Beyhakî, es-Sünenü'l-Kübrâ, 2/314.

111 "Bazı fakihler secdede kolları yere yapıştırmaktan meneden rivayetin sadece erkeklere has olduğu görüşündedirler.” el-Mevsûatu'l-Fıkhıyye (Kuveyt: Vizaratü'l-Evkâf, 1427), 5/277. Ancak bu görüşü destekleyecek bir rivayet ya da uygulama tespit edilememiştir.

112 Müslim, "Salât", 493.

113 Serahsî, el-Mebsût, 1/23; İbn Ebî Şeybe, el-Musannef, 1/241, Abdürrezzâk, el-Musannef, 3/138; Beyhakî, es-Sünenü'l-Kübrâ, 2/314; A. Fikri Yavuz, İslam İlmihali, 136; Lütfi Şentürk-Seyfettin Yazıcı, İslam İlmihali, 133.

114 Ebû Ali Huseyn el-Merverrûzî, et-Ta'lika li Kadı Hüseyn, thk. A. Muhammed Avvaz (Mekke: Mektebetü Nezzâr, ts.), 2/812-813; İbn Kudâme, el-Muğnî, 1/403; Ebû Şücâ‘ el-Isfahânî, Delilleriyle Büyük Şâfiî İlmihali, çev. Nizameddin Ersöz (İstanbul: Ravza Yayınları, 2005), 180.

115 İbn Manzur, Lisânü'l-'Arab, 3/239; Fahrettin Atar, "Teşehhüd”, Türkiye Diyanet Vakfi İslam Ansiklopedisi (İstanbul: TDV Yayınları, 2011), 40/563-564.
} 


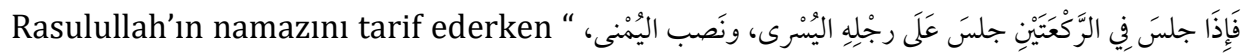
Illk iki rekattan sonra (ilk teşehhüde) oturduğunda sağ ayağını dikip sol ayağı üstüne otururdu. Son rekatta ise, sağ ayağını dikip sol ayağını sağ ayağı altına yatırarak (sol) makadı üzerine otururdu" demiştir. ${ }^{116}$

Hadisten de anlaşılacağı üzere Hz. Peygamber (s.a.s.) iki rekattan sonraki ilk oturuşta iftiraş (sağ ayağı dikip sol ayağı yatırarak üzerine oturmak) şeklinde, selamdan önceki son oturuşta ise teverrük şekline (sol makad üzerine oturarak iki ayağı sağ taraftan çıkarmak) yakın şekilde oturmuştur. Bunun yanı sıra Hz. Peygamber'in oturuş şekillerinden sadece birini ihtiva eden başka rivayetler de vardır.

2. İbn Zübeyr (r.a.): Hz. Peygamber (s.a.s.) namazda oturduğunda قَعَل قدمَهُ

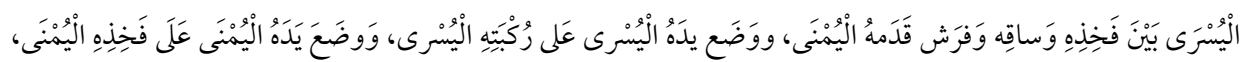
sol ayağını uyluk ile baldırı arasına koyar ve sağ ayağını da yere yayardı. Sol elini sol dizi, sağ elini de sağ uyluğunun üzerine koyardı. Ayrıca parmağı ile işaret ederdi" demiştir ${ }^{117} \mathrm{Bu}$ rivayette Hz. Peygamber'in teverrük şeklinde oturduğundan söz edilmiştir.

3. Vâil (r.a.) şöyle demiştir. "Medine'ye geldiğimde kendi kendime 'mutlaka

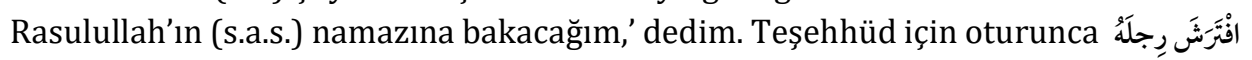

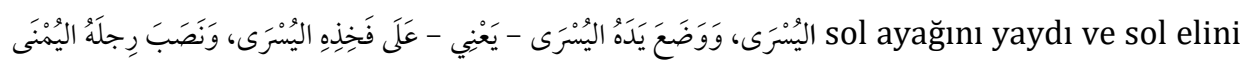
sol uyluğu üstüne koydu. Sağ ayağını da dikti."118 Tirmizî‘nin "hasen sahih” dediği bu hadis Hz. Peygamber'in iftiraş şeklinde oturduğunu haber vermektedir.

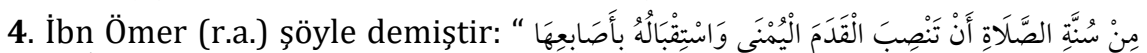

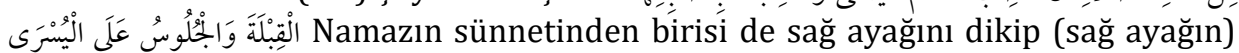
parmaklarını kıbleye doğru çevirmen ve sol ayağın üzerine oturmandır."119

$\mathrm{Bu}$ rivayet, diğer rivayetlerden farklı olarak teşehhüdde sağ ayağın parmaklarının kıbleye doğru çevrilmesi gerektiğinden söz etmektedir. Ancak bu durum ifrirâş üzere oturulduğunda mümkündür.

Hz. Peygamber'in (s.a.s.) teșehhüdünü haber veren bu rivayetlerden çıkarabilecek sonuçlar şunlardır: İlk teşehhüd ile son teşehhüdde gerçekleștirilen oturuş şekilleri birbirinden farklıdır. Hz. Peygamber teşehhüdünü şu üç halden biri üzere tatbik etmiştir: iftiraş, teverrük, yarı teverrük (sağ ayağı dikip, sol ayağını sağ ayağının altına koyup makadı üzere oturmak) Hz. Peygamber ifrirâş üzere oturduğunda sağ ayağını dikip, parmaklarını da kıbleye gelecek şekilde kıvırmıștır. Hz. Peygamber bu uygulamaların her birini farklı zamanlarda gerekleştirmiş olabilir.

116 Buhârî, “Ezân”, 145; Ebû Dâvûd, “Salât”, قعد متوركـ ibaresi yer almaktadır; Tirmizî, “Salât”, 219’da bu hadisi farklı tarikle ve sadece iftiraş kısmını zikrederek vermiştir.

117 Müslim, "Mesâcid", 579.

118 Tirmizî, "Salât", 128; Ebû Dâvûd, "Salât", 114; Nesâî, "İftitâh”, 10.

119 Nesâî, "Tatbîk" 95. 
Hanefî mezhebinin görüşü teşehhüdde iftiraş şeklinde oturmaktır. Teverrük üzere oturmanın yaşlılık ve hastalık gibi özür hallerine mahsus olduğu görüşündedirler. Mâlikî mezhebine göre her iki teşehhüdde de teverrük üzere oturmak sünnettir. İmam Şâfiî birinci teşehhüdde iftiraş üzere oturulmasını esas alır. Çünkü birinci teşehhüdden sonra ayağa kalkılacağı için iftiraş üzere oturmak bunu kolaylaştıracaktır. Son teșehhüdde ise teverrük üzere oturulacağı görüşündedir. İbn Hanbel de İmam Şâfiî ile aynı görüştedir. ${ }^{120}$

\subsection{Kadınların Teșehhüdde Oturuş Şekline Dair Rivayetler}

Hz. Peygamber'in (s.a.s.) teșehhüdünün hem iftiraș, hem de teverrük üzere olduğundan söz edildi. Bu başlık altında kadınların teșehhüdü ile ilgili tespit edilen rivayetler incelenecektir.

1. İbn Ömer'den (r.a.) rivayetle Rasulullah (s.a.s.): “ فَخِذَهَا عَلَ فَخِذِهَا الْْخُخْرى Kadın namazda oturduğunda, bir uyluğunu diğer uyluğu üzere koyar..." buyurmuştur. ${ }^{121}$

Kadının nasıl secde edeceğiyle ilgili rivayetleri zikrederken bu hadis geçmiş ve zayıf bir rivayet olduğundan söz edilmişti. Rivayetin ilk cümlesi namazda oturma ile ilgili olduğundan burada tekrar zikredildi. Rivayette tarif edilen şekil, bir uyluğun diğer uyluk üzerine konması şeklindedir ki bu da adı zikredilmemekle birlikte teverrük şeklinde oturmakla gerçekleşebilecek bir haldir.

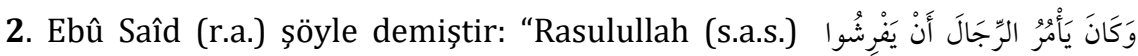
erkeklerin teşehhüdde sol ayağını yayıp sağ ayağını dikerek oturmalarını söylerken kadınların bağdaş kurarak oturmalarını emrederdi." 122

Kadınların secdesi konusunda incelenen bu zaylf rivayet kadınların teşehhüdde nasıl oturacakları ile ilgili emri de ihtiva etmektedir. Hadiste geçen تربع kelimesi "bağdaş kurup oturmak" anlamına gelmektedir. ${ }^{123}$ Hadisteki emir kadınların teşehhüde oturduklarında bağdaş kurarak oturmaları yönündedir.

Kadın erkek ayrımından söz edilmeksizin namazda bağdaş kurarak oturma ile ilgili Buhârî'nin Sahîh'inde yer alan rivayet bu durumun "hastalık veya yaşlılık sebebiyle" uygulanabileceğini haber vermektedir.

İbn Abdullah şöyle demiştir: "Babam İbn Ömer'in namazda teşehhüde bağdaş kurarak oturduğunu görmüştüm. Ben de onun yaptığı gibi bağdaş kurup oturdum. $O$ vakitler küçüktüm. Babam böyle yapmamam konusunda beni uyarıp şöyle demiști: 'Namazda sünnet olan sağ ayağını dikip sol ayağını yatırmandır.' Ben: 'Fakat sen de bağdaş kuruyorsun' dediğimde: "Ayaklarım vücudumu taşımıyor ki!"

120 Serahsî, el-Mebsût, 1/24-25; Ebubekir Sifil, "Ka'de", Türkiye Diyanet Vakfı İslam Ansiklopedisi (İstanbul: TDV Yayınları, 2001), 24/55.

121 Beyhakî, es-Sünenü'l-Kübrâ, 2/315.

122 Beyhakî, es-Sünenü'l-Kübrâ, 2/314.

123 İbrahim Mustafa vd., el-Mu'cemü'l-Vasît, (b.y.: Dâru'd-Da've, ts.), 324. 
diye cevap vermişti. ${ }^{124}$

Kadınların bağdaș kurarak oturmasına dair başka rivayetler de mevcuttur. 0 rivayetleri naklettikten sonra kadınların bağdaş kurmasına dair genel bir değerlendirmede bulunmaya çalışacağız.

3. İbn Ömer'e: “Kadınlar Rasulullah (s.a.s.) zamanında nasıl namaz kılarlardı?” diye sorulunca şöyle cevap vermiştir: “ثم أمرن أن يحتفزن كن يَتَرَبَّنْنَ Onlar bağdaş kurup oturuyorlardı. Sonra uyluklarını birleştirerek oturmaları emredildi."125

Ebû Hanîfe'ye nispet edilen Müsned adlı eserde yer alan bu rivayet, Nâfi'den ö. (117/735) Ebû Hanîfe'ye ulaşmıştır. Tehânevî ö. (1158/1745) isnadının sahih olduğunu söyler. ${ }^{126}$

Rivayette kadınların namaz kılarken bağdaş kurarak oturdukları ancak daha sonra farklı bir uygulamanın muhatabı oldukları haber verilmektedir. Bağdaş kurarak oturmanın neshi ile ilgili de bir bilgi tespit edilememiştir. Rivayette daha önceki uygulama يتربعن fiili ile anlatılmıştır. Bu fiilin bağdaş kurmak anlamına geldiğinden söz edilmişti. Sonraki emrin haber verildiği يحتفزن fiili kadınların secde ediş şekillerinde de geçtiği üzere derlenip toparlanmayı ifade etmektedir. Ali el-Kârî bu rivayetten bahsederken "ihtifâz" kelimesini "uzuvlarını birleștirip, teverrük üzere otururlar" şeklinde açıklamıştır. ${ }^{127}$

Hz. Âişe'nin (r.a.) oturuşu ile ilgili İbn Receb'in ö. (795/1393) zikrettiği şu rivayete de burada yer vermeyi uygun gördük: Saîd b. Mansûr'un isnadiyla كانت " Abdurrahman b. Kâsım'dan naklettiğine göre Abdurrahman şöyle demiştir: Hz. Âişe namazda makadı üzerine oturur, uyluklarını birleştirirdi. Bazen de bağdaş kurarak otururdu." 128

Tam isnadını tespit edemediğimiz bu rivayeti İbn Receb, Buhârî’nin “ باب سنة كانت أم الدرداء تجلس في صلاتها جلسة bâbının hemen altında ta'liken zikrettiği الجلوس في التشهد “Ümmü'd-Derdâ namazda erkeklerin oturduğu şekilde otururdu. 0 fakîh bir kadındı" cümlesini açıklarken zikretmiştir. ${ }^{129}$

Abdurrahman b. Kâsım, Hz. Âişe'nin teşehhüdünden söz ederken iki farklı uygulamadan bahsederek, hem uyluklarını birleştirdiğinden (teverrük) hem de bağdaş kurduğundan söz etmiştir.

\footnotetext{
124 Buhârî, "Ezan” 145.

125 Ebû Hanîfe Numan b. Sâbit, Müsned -Haskefî rivayeti- (Mısır: el-Âdâp, ts.), Kitâbü’s-Salât, hadis no: 37; Ebü'l-Müeyyed el-Hârîzmî, Câmiu'l-Mesânîd (Hindistan: Matbâaü Meclisi Dâiretü'l-Maarif, 1332/1914), 1/400.

126 Tehânevî, İlâüs'Sünen, 3/27.

127 Ali el-Kârî, Şerhu Müsnedi Ebî Hanîfe, 1/191.

128 Zeynüddin İbn Receb el-Hanbelî, Fethu'l-Bârî (Medine: Mektebetü'l- Gurabai'l- Eseriyye, 1996), 7/300; Saîd b. Mansûr'un Süneni'nde Abdurrahman b. Kâsım'dan farklı konularda sadece iki rivayet nakledilmiştir. Onun Hz. Aişe'nin namaz kılışına dair rivayetini tespit edemedik. Ancak bu Sünen günümüze tam olarak ulaşamadığından rivayetin bulunamaması tabiidir.

129 Buhârî, "Ezan”, 145.
} 
Konuyla ilgili olarak tâbiînden gelen görüşler incelendiğinde, kadınlara bağdaş kurarak oturmalarının emredildiğinden, erkeklerin oturduğu gibi oturabileceklerinden, kolayına nasıl gelirse o şekilde oturacağından, teverrük üzere oturmasının daha güzel olduğundan söz edildiği görülmektedir. ${ }^{130}$

Kadınların teşehhüdüne dair rivayetlerin incelenmesinden sonra bizde oluşan kanaat, İbn Ömer (r.a.) rivayetinde geçtiği üzere, kadınlara bağdaş kurarak oturmalarının tavsiye edildiği ancak daha sonraları bu tavsiyenin yerini bir uyluğu diğer uyluk üzere koyarak iki uyluğu birbirine bitiştirmek şeklinde oturmanın aldığı şeklindedir.

Mezheplerin bu konudaki görüşlerine gelince; Hanefî mezhebi kadının namazda teverrük üzere oturması gerektiğini söyler. Ancak Ebû Hanîfe kadının erkekler gibi de oturabileceği görüşündedir ${ }^{131}$ Şâfiî ve Mâlikî mezhebine göre kadın ve erkeğin namazda oturuşları arasında herhangi bir fark yoktur. Şâfiî mezhebinde birinci teşehhüdde iftiraş üzere oturulurken son teşehhüdde teverrük üzere oturulur. Mâlikîler'de her iki teşehhüdde de teverrük üzere oturmak esastır. Ancak Şâfiî kaynaklarda kadının teverrük üzere oturmasının daha iyi olduğu zikredilmiştir. ${ }^{132}$ Kadı Iyaz ö. (544/1149) ve seleften bazıları kadının bağdaş kurarak oturması görüşündeyken selefin bir kısmı bağdaşın nafile namazlara mahsus bir oturuş olduğunu söylemişlerdir. ${ }^{133}$ İbn Hanbel kadının teșehhüdde teverrük üzere oturmasının daha güzel olacağı görüşündedir. ${ }^{134}$

\section{Sonuç}

İslam dininin kelime-i şahadetten sonra en önemli esası olan namaz ibadeti, müslümanın hayatında önemli bir yere sahiptir. Hz. Peygamber (s.a.s.) namaza dair ne varsa müslümanlara öğretmiş ve onlara namazı kendisinden gördükleri şekilde uygulamalarını emretmiştir. Bununla birlikte kadınların bazı rükünleri erkeklerden farklı şekilde uyguladıkları görülmektedir. Rivayetlerin sunduğu veriler neticesinde kadının namaz kılış şekli ile ilgili şunlar söylenebilir:

1. Vâil'den gelen rivayetin isnadındaki raviler, hakkında bilgi bulunamayan (meçhul) iki kişi haricinde sikadır. Bu hadis konuyla ilgili bize ulaşan tek rivayet olup zayıf bir rivayettir ve kendisiyle amel edilebilir. Bu rivayete göre kadınlar tekbir getirirken ellerini göğ̈̈sleri hizasına kadar kaldırmalıdır.

2. Kadınlar, kıyamda kendilerine mahsus bir emrin günümüze ulaşmamış olması sebebiyle Hz. Peygamber'den gelen uygulamalardan birine (sağ elini sol eli üzerine koyması, sağ eliyle sol elinin bileğini kavraması, sağ elini sol kolunun üzerine koyması, ellerini göğüs, göbek altı ve her ikisi arasına yerleștirmesi) tâbi olur.

\footnotetext{
${ }^{130}$ Abdürrezzâk, el-Musannef, 3/138-139; İbn Ebî Șeybe, el-Musannef, 1/242-243.

${ }^{131}$ Serahsî, el-Mebsut, 1/25; Aynî, Umdetü'l-Kârî (Beyrut: Dâru İhyâi't-Türâsi'l-Arabî, ts.), 6/101; Illmihal Iman ve Ibadetler, 254.

${ }^{132}$ Nevevî, el-Minhâc, 4/215; Hatîb eş-Şirbînî, Muğni'l-Muhtâc (Beyrut: Dâru'l-Kütübi'l-İlmiyye 1994), $1 / 350$.

133 Nevevî, el-Minhâc, 4/215.

134 İbn Kudâme, el-Muğnî, 1/403.
} 
3. Hanefî mezhebine mensup kadınların farklı şekilde tatbik ettikleri rükün rükûdur. Bu uygulamanın ilk dönemden itibaren amel edilegelerek bize ulaşmış olması muhtemeldir. Hanefî mezhebinde hanımların rükûu için yapılan farklı tarif anlayabildiğimiz kadarıyla bir ictihattan ziyade Kur'an'daki rükû emrini mutlak olarak almalarından, rükû ve itmi'nan'ın (rükû yaparken bir süre bekleme) arasını ayırmalarından kaynaklanmaktadır. Mezhepte müftâ bih (tercih edilen) olan görüş tuma'nînenin farz değil, vacip olduğudur. Buna göre kişi rükûa yakın bir eğilme ile bu emri yerine getirmiş olur. Ancak namazın en güzel şekilde edâsı ta'dîl-i erkân iledir. Mezhebin rükû emrini anlaması ile kadınların rükûuna dair yaptığı tarif kendi içerisinde tutarlı olmakla birlikte bu uygulamaya dair bir rivayete ulaşılamamıștır.

4. Secde hususunda iki merfu, bir mürsel ve bir mevkuf olmak üzere toplam dört rivayet tespit edilmiştir. Yapılan inceleme sonucunda mürsel rivayet haricindeki hadislerin zayıf olduğu sonucuna ulașılmıştır. Ancak rivayetlerin birbirini desteklediği kabul edilecek olursa bunlardan çıkan sonuç, kadının secde ederken kollarını yanlarına yapıştırması, uyluklarını birleştirmesi ve erkeklerden daha derli toplu durmasıdır.

5. Teşehhüd konusunda incelenen rivayetlerle birlikte, tam senedine ulaşamadığımız haber (Hz. Âișe'nin oturușu) ile tâbiînden gelen rivayetleri de konunun açıklanmasına kaynaklık etmesi yönüyle ele aldık. Bu rivayetlere göre kadının teşehhüdde teverrük üzere oturması tavsiye edilmiştir.

Sonuç olarak kadınların tekbir, secde ve teşehhüdü hususunda rivayetlere ulaşılmış, elleri bağlama ve rükûu ile ilgili merfu ya da mevkuf bir rivayet tespit edilememiștir.

Funding / Finansman: This research received no external funding. / Bu araștırma herhangi bir diş fon almamıştır.

Conflicts of Interest / Çıkar Çatışması: The author declare no conflict of interest. / Yazar, herhangi bir çıkar çatışması olmadı̆̆ını beyan eder.

\section{Kaynakça}

Abdürrezzâk, Ebû Bekr Abdürrezzâk b. Hemmâm b. Nâfî'es-San'ânî el-Himyerî. el-Musannef. thk. Habîburrahman el-A'zamî. 11 Cilt. Beyrut: el-Mektebü'l-İslâmî, 1983.

Ali el-Kârî, Ebü'l-Hasen Nûrüddîn Ali b. Sultân Muhammed el-Herevî. Serhu Müsnedi Ebî Hanîfe. thk. Halil Muhyiddin. Beyrut: Dâru'l-Kütübi'l-İlmiyye, 1985.

Atar, Fahrettin. "Teșehhüd”. Türkiye Diyanet Vakfi İslam Ansiklopedisi. 40/563-564. İstanbul: TDV Yayınları, 2011.

Aydınlı, Abdullah. Hadis Istılahları Sözlüğü. İstanbul: Timaș Yayınları, 1987.

Aynî, Ebû Muhammed Bedreddîn Mahmûd b. Ahmed b. Musâ. el-Binâye Șerhu'l-Hidâye. 12 Cilt. Beyrut: Dâru'l- Kütübi'l-İlmiyye, 2000.

Aynî, Bedreddîn. Umdetü'l-Kârî fi Şerhi Sahihi'l-Buhârî.Beyrut: Dâru İhyâi't-Türâsi'l-Arabî, ts. Beyhakî, Ebû Bekr Ahmed b. Hüseyn b. Ali. es-Sünenü'l-Kübrâ. thk. M. Abdülkâdir Ata. 3 Cilt. Beyrut: Dâru'l- Kütübi'l-İlmiyye, 2003.

Beyhakî, Ebû Bekr. es-Sünenü'l-Kebîr. çev. Hüseyin Yıldız, vd. İstanbul: Ocak Yayıncılık, 2016. Beyhakî Ebû Bekr. Ma'rifetü's-Sünen. thk. Emin Kal'aci. 15 Cilt. Kahire: Dâru'l-Vefâ, 1991.

Bezzâr, Ebû Bekr Ahmed b. Amr b. Abdilhâlik el-Basrî. el-Bahrü'z-Zehhâr Müsnedü'l-Bezzâr. 
thk. Mahfuzu'r-Rahman Zeynullah, vd. Medine: Mektebetü'l-Ulûm ve'l-Hikem, 2009. Bilmen, Ömer Nasuhi. Büyük İslam İlmihali. İstanbul: Bilmen Yayınevi, ts.

Buhârî, Ebû Abdillâh Muhammed b. İsmâîl b. İbrahim el-Cû́fî. el-Câmiu's-Sahîh. nșr. M. Züheyr b. Nâsır en-Nâsır. 8 Cilt, Beyrut: Daru Tavki'n-Necât, 1. Basım, 2001.

Buhârî, Ebû Abdillâh Muhammed b. İsmâîl. Raf'ul-Yedeyn fi's-Salât. thk. Ahmed eș-Șerîf, Kuveyt: Dâru'l-Erkâm, 1983.

Çalışkan, Hasan. Hanımlara İlmihal. Konya: Serhat Kitabevi, 2005.

Çelik, Taha. Hadis Mezhep İhtilaf (Beyhakî'nin Tahâvi'ye İtirazları). Konya: Palet Yayınları, 1. Basım,2019.

Dalgın, Nihat. "Rükû". Türkiye Diyanet Vakfı İslam Ansiklopedisi. 35/286. İstanbul: TDV Yayınları, 2008.

Dalgın, Nihat. "Secde”. Türkiye Diyanet Vakfı İslâm Ansiklopedisi.36/271-272. İstanbul: TDV Yayınları, 2009.

Duman, Soner. Ayet ve Hadislerle Şâfiî İbadetler İlmihali. İstanbul: Miraç Yayınları, 2013.

Ebû Dâvûd, Süleymân b. el-Eş'as b. İshak es-Sicistânî el-Ezdî. el-Merâsil. thk. Şuayb elArnavud. Beyrut: Müessetü'r-Risâle, 1998.

Ebû Dâvûd, Süleymân es-Sicistânî. es-Sünen. 4 Cilt. Beyrut: el-Mektebetü'l-Asriyye, ts.

Ebû Dâvûd, Süleymân es-Sicistânî. Sünen-i Ebû Dâvûd Terceme ve Şerhi. çev. İ. Lütfi Çakan.16 cilt. İstanbul: Şamil Yayınevi, 1987.

Ebû Hanîfe, Numan b. Sâbit. Müsned -Haskefî rivayeti- Mısır: el-Âdâp, ts.

Ebû Nuaym Ahmed b. Abdillâh b. İshak el-İsfahânî. Târihu İsfehan. thk. S. Kisrevî Hasan. 2 Cilt. Beyrut: Dârû'l-Kütübi'l-İlmiyye.

Ebû Şûcâ, Kadı Ahmed b. Hüseyin. Delilleriyle Büyük Şâfiî Illmihali. çev. Nizameddin Ersöz İstanbul: Ravza Yayınları, 2005.

Elbânî, Muhammed Nâsıruddin. Aslu Sıfati Salâti'n-Nebî. Rıyad: Mektebetü'l-Maarif, 2006.

Hâcce, Kevkeb 'Ubeyd. Fıkhu'l-İbâdât alâ Mezhebî Mâlikî. Suriye: Matbaatü'l-İ̉nşâ', 1986.

Hatîb el-Bağdâdî, Ebû Bekr Ahmed b. Ali b. Sâbit. el-Kifâye fî İlmi'r-Rivâye. thk. Abdullah esSûrakî. Medine: el-Mektebetu'l-İlmiyye, ts.

Hattâbî, Ebû Süleyman Hamd (Ahmed) b. Muhammed b. İbrahîm b. Hattâb el-Büstî. Meâlimu's-Sünen. Haleb: el- Matbaatü'l-İlmiyye, 1932.

Haddâd, Ebû Bekr b. Ali. el-Cevheretü'n-Neyyire. 2 Cilt. b.y.: Matbaatü'l-Hayriyye, 1904.

Hârîzmî, Ebü'l-Müeyyed. Câmiu'l-Mesânîd. Hindistan: Matbâatü Meclisi Dâiretü'l-Maarif, ts.

Heysemî, Ebü'l-Hasen Nurüddîn Ali b. Ebî Bekr b. Süleymân. Mecmau'z-Zevâid ve Menbau'lFevâid. thk. Hüsameddin el-Kudsî. 10 Cilt. Kâhire: Mektebetü'l-Kudsî, 1994.

İbn Âbidîn, Muhammed Emin b. Ömer b. Abdilazîz el-Hüseynî. Reddü'l-Muhtar ale'd-Dürri'lMuhtar. 6 Cilt. Beyrut: Dâru'l-Fikr, 1992.

İbn Ebî Şeybe, Ebû Bekr Abdullah b. Muhammed. el-Musannef fíl-Ehâdîs ve'l-Âsâr. thk. K. Yusuf el-Hût. 7 Cilt. Riyad: Mektebetü'r-Rüșt, 1409/1989.

İbn Furek, Ebû Bekr Muhammed. Müşkilü'l-Hadis ve Beyânühû. thk. M. Muhammed Ali. Beyrut: Âlimü'l-Kütüb, 1985.

İbn Hacer el-Askalânî, Ebü'l-Fadl Ahmed b. Ali. Lisânü'l-Mîzân. Abdülfettah Ebû Gudde. 7 Cilt. Beyrut: Dârü'l-Beşâiri'l-İslâmiyye, 2002.

İbn Hacer el-Askalânî. Takrîbü't-Tehzîb. thk. Muhammed Avvâme. Suriye: Dârü'r-Reșîd,1986.

İbn Hacer el-Askalânî. Tehzîbü't-Tehzîb. 12 Cilt. Hindistan: Matba'atü Dâirati'l-Meârifi'nNizâmiyye, 1909.

İbn Huzeyme, Ebû Bekr Muhammed b. İshak b. Huzeyme es-Sülemî. es-Sahîh. thk. M. Mustafa el-A'zamî. 2 Cilt. Beyrut: Mektebet'ül-İslâmî, 1992.

İbn Hümam, Kemaleddin Muahmmed. Fethu'l-Kadir. 10 Cilt. b.y.: Dâru'l-Fikr, ts.

İbn Kudâme, Muvaffakuddin. el-Muğnî. 10 Cilt. Kahire: Mektebetü'l-Kâhire, 1968.

İbn Manzur, Ebü'l-Fadl Cemalüddîn. Lisânü'l-Arab. 15 Cilt. Beyrut: Dârü Sâdır, 1994.

İbn Nüceym, Zeynüddîn b. İbrahîm b. Muhammed el-Mısrî. el-Bahru'r-Râik Şerhu Kenzi'dDekâik. 7 Cilt. b.y.: Daru'l-Kütübi'l-İslamî, ts.

İbn Receb el-Hanbelî, Ebü'l-Ferec Zeynüddîn Abdurrahmân b. Ahmed el-Bağdâdî. Fethu'l- 
Bârî Şerhu Sahih-i Buhârî.7 Cilt. Medine: Mektebetü'l- Gurabai'l- Eseriyye, 1996.

İbnü'l-Esîr, Ebu's-Saadât Mecdüddîn el-Mübarek b. Esîrüddîn. en-Nihâye fí Garîbi'l-Hadîs ve'lÂsâr. thk. T. Ahmed ez-Zavi. 5 Cilt. Beyrut: el-Mektebetü'l-İlmiyye, 1979.

İbnü'l-Müneccâ, Zeynüddîn. el-Mümtı' fi Șerhi'l-Muğnî. Mekke: Mektebetü'l-Esedî, 2003. Kâsânî, Alâüddîn . Bedâiu's-Sanâi' fi Tertîbi'ş-Șerâi. b.y.: Dâru'l-Kütübi'l-İlmiyye, 1986.

Keskin, Zahide. Uygulama ve Delilleri Açısından Namazda Ellerin Durumu. Yüksek Lisans Tezi, Recep Tayyip Erdoğan Üniversitesi, 2016.

Köse, Saffet. "Tekbir". Türkiye Diyanet Vakfi İslam Ansiklopedisi. 40/341-343. İstanbul: TDV Yayınları, 2011.

Mâlik b. Enes, Ebû Abdullah el-Asbahî. el- Muvattâ. thk. Beşşar Avvâd vd. 2 Cilt. Beyrut: Müessesetü'r-Risâle, 1992.

Mergīnânî, Ebü'l-Hasen Burhânüddin Ali b. Ebî Bekr. el-Muhîtü'l-Burhânî fi'l-Fıkhi'n-Nu'mânî. thk. A. Sami el-Cündî. 9 Cilt. Beyrut: Dârü'l-Kütübi'l-İlmiyye, 2004.

Merverrûzî, Ebû Ali el-Hüseyn b. Muhammed b. Ahmed. et- Ta'lika li Kadı Hüseyn. thk. A. Muhammed Avvaz. 2 Cilt. Mekke: Mektebetü Nezzâr, ts.

Mizzî, Ebü'l-Haccâc Cemâlüddîn Yusuf b. Abdirrahmân. Tehzîbü'l-Kemâl fí Esmâi'r-Ricâl. thk. Beșşâr Avvâd. 35 Cilt. Beyrut: Müessesetü'r-Risâle, 1980.

Molla Hüsrev, Mehmed b. Ferâmurz. Dürerül-Hükkâm fí Șerhi Gureri'l-Ahkâm. 2 Cilt. Beyrut: Dâru İhyai't-Türâsi'l-Arabî, ts.

Müslim, Ebü'l-Hüseyn el-Kuşeyrî. el-Câmi'us's-Sahîh. thk. M. Fuat Abdülbâkî 5 Cilt. Beyrut: Dâru İhyâi't-Türâsi'l-Arabî, ts.

Nesâî, Ebû Abdirrahman Ahmed b. Şuayb b. Ali. Sünen. thk. Abdufettah Ebû Gudde. 8 Cilt. Halep: Mektebetü'l- Matbuâti'l-İslâmiyye, 1986.

Nevevî, Ebû Zekeriyyâ Yahyâ. el-Minhâc Şerhu Sahihi Müslim b. el-Haccâc. 18 Cilt. Beyrut: Dâru İhyai't-Türâsi'l-Arabî, 1972.

Nevevî, Ebû Zekeriyyâ. el-Mecmû'SSerhu'l-Mühezzeb. Beyrut: Dâru'l-Fikr, ts.

Polat, Selahattin. Mürsel Hadisler ve Delil Olma Yönünden Değeri. Ankara: Türkiye Diyanet Vakfı, 2. Basım, 2010.

Râgıb el-İsfahânî, Ebü'l-Kâsım Hüseyn b. Muhammed. el-Müfredât fi Garîbu'l-Kur'an. thk. S. Adnan Dâvûdî, Dımeşk: Dâru'l-Kalem, 1991.

Sehârenpûrî, Halil b. Ahmed b. Mecîd. Bezlü'l-Mechûd fi Halli Süneni Ebî Dâvûd. thk. M. İdris Kandehlevî. 20 Cilt. Beyrut: Dâru'l- Beşâiru'l-İslamiyye, 2006.

Semerkandî, Alâuddin. Tuhfetu'l-Fukahâ. 3 Cilt. Beyrut: Dâru'l-Kütübi'l-İlmiyye, 1994.

Serahsî, Ebû Bekr Șemsü'l-eimme. el-Mebsût. 30 Cilt. Beyrut. Dâru'l-Mârife, 1993.

Sifil, Ebubekir. "Kıyam". Türkiye Diyanet Vakfı İslam Ansiklopedisi. 25/514-515 İstanbul: TDV Yayınları, 2002.

Sifil, Ebubekir. "Ka'de". Türkiye DiyanetVakfi İslâm Ansiklopedisi. 24/55. İstanbul: TDV Yayınları, 2001.

Şâfiî, Ebû Abdillâh Muhammed b. İdrîs b. Abbâs. el-Ümm. 7 Cilt. Beyrut: Dâru'l- Marife, 1990.

Șener, Mehmet. "Ebû Mutî' el-Belhî”. Türkiye Diyanet Vakfı İslâm Ansiklopedisi.10/194-195. İstanbul: TDV Yayınları,1994.

Şentürk, Lütfi -Seyfettin Yazıcı. İslam İlmihali. Ankara: DİB Yayınları. 15.Basım, 2009.

Şîrâzî, Ebû İshak Cemâlüddîn İbrahîm b. Ali. el-Mühezzeb fi Fıkhi el-İmam eș-Şâfiî. 3 Cilt. Beyrut: Dâru'l-Kütübi'l-İlmiyye, ts.

Şirbînî, Şemsüddîn Muhammed b. Ahmed el-Hatîb. Muğni'l-Muhtâc ilâ Ma'rifeti Meânî Elfâzı'l-Minhâc. 6 Cilt. Beyrut: Dâru'l-Kütübi'l-İlmiyye 1994.

Taberânî, Ebü'l-Kâsım Süleyman b. Ahmed b. Eyyûb. el-Mu'cemü'l-Kebîr. thk. Hamdi esSelefî. 25 Cilt. Kahire: Mektebetü İbn Teymiye, 1994.

Tahâvî, Ebû Cafer Ahmed. Şerhu Meâni'l-Âsâr. 4 Cilt. Beyrut: Âlimü'l-Kütüb, 1994.

Tehânevî, Zafer Ahmed. I'lâü’s-Sünen. thk. M. Takî Osmanî. 22 Cilt. Karaçi: İdârâtu'l-Kurân ve'l-Ulûmu'l-İslâmiyye, 1418/1972.

Tirmizî, Muhammed b. Îsa. Sünenü't-Tirmizî. thk. A. Muhammed Şakir vd. Kahire: Matbaatü Mustafa el-Bâbi'l- Haleb, 2. Basım, 1975. 
Yaşaroğlu, M. Kamil. "Namaz". Türkiye Diyanet Vakfı İslam Ansiklopedisi. 32/350-357. İstanbul: TDV Yayınları, 2006.

Yavuz, A. Fikri. İslam İlmihali. İstanbul: Çile Yayınları, ts.

Yılmaz, Muhammed. "Mevkuf Hadisler ve Hükmen Merfu Kavramı". Çukurova Üniversitesi İlahiyat Fakültesi Dergisi 1/1 (2001), 161-179.

Zehebî, Ebû Abdillah Șemsüddin el-Kâșif fi Ma'rifeti men lehû Rivâye fi'l-Kütübi Sitte. thk. Muhammed Avvame. Cidde: Dâru'l-Kıbleli's-Sekâfeti'l-İslâmiyye,1992.

Zehebî, Ebû Abdillah Şemsüddin Muahmmed b. Ahmed b. Osman. Mîzânü'l-I'tidâl fí Nakdi'rRicâl. thk. A. Muhammed el-Bicâvî. 4 Cilt. Beyrut: Dâru'l-Mârife, 1963.

Zehebî, Ebû Abdillah Șemsüddin. Târîhu'l-İslâm ve Vefâyati'l-Meșâhîr ve'l-Â'lâm. thk. Beșşâr Avvâd. 15 Cilt. Tunus: Dârü'l-Garbi'l-İslâmî, 2003.

Zeylaî, Osman. Tebyînü'l-Hakâyık Șerhu Kenzi'd-Dekâik. Kahire: el-Matbaatü'l-Kübrâ,1869. 